MARIANGELA BENTO

Grupos Terapêuticos em Instituição de Saúde:

a relação entre a intersubjetividade e o

intrapsíquico na Psicanálise

São Paulo

2006 
MARIANGELA BENTO

Grupos Terapêuticos em Instituição de Saúde:

a relação entre a intersubjetividade e o

intrapsíquico na Psicanálise

Dissertação apresentada ao Instituto de Psicologia da Universidade de São Paulo, como parte dos requisitos para obtenção do título de Mestre em Psicologia Clínica.

Área de Concentração: Psicologia Clínica Orientadora: Prof ${ }^{\mathrm{a}}$. Dr ${ }^{\mathrm{a}}$. Elisa Maria Parahyba Campos

São Paulo

2006 
Autorizo a reprodução e divulgação total ou parcial deste trabalho, por qualquer meio convencional ou eletrônico, para fins de estudo e pesquisa, desde que citada a fonte.

Catalogação na publicação

Serviço de Biblioteca e Documentação

Instituto de Psicologia da Universidade de São Paulo

Bento, Mariangela.

Grupos terapêuticos em instituição de saúde: a relação entre a intersubjetividade e $o$ intrapsíquico na psicanálise Mariangela Bento; orientadora Elisa Maria Parahyba Campos. -São Paulo, 2006.

$80 \mathrm{p}$.

Dissertação (Mestrado - Programa de Pós-Graduação em Psicologia. Área de Concentração: Psicologia Clínica) - Instituto de Psicologia da Universidade de São Paulo.

1. Psicanálise 2. Grupos 3. Subjetividade I. Título. 


\section{Grupos Terapêuticos em Instituição de Saúde: a relação entre a intersubjetividade e o intrapsíquico na Psicanálise}

MARIANGELA BENTO

BANCA EXAMINADORA

Prof $^{a}$ Dra. Elisa Maria Parayba Campos

Orientadora

Profa. Dra. Isabel Cristina Gomes

Profa. Dra . Kátia da Silva Wanderley 


\section{Dedico este trabalho...}

aos meus pais

Annibal (in memoriam)

Herança de dignidade e trabalho

Mathilde

Exemplo de perseverança e dedicação 


\section{AGRADECIMENTOS}

À Profa. Dra. Elisa Maria Parahyba Campos, minha orientadora, pela confiança no meu trabalho, pela segurança que me transmitiu e, principalmente, por acolher minhas angústias.

Às Profas. Dras. Kátia da Silva Wanderley e Isabel Cristina Gomes, por todas as valiosas contribuições, quando do Exame de Qualificação.

À Profa. Livre Docente Maria Inês Assumpção Fernandes, pelas indicações teóricas e por colocar as coisas no seu devido lugar e tempo.

Aos Prof $^{\circ}$ s. Dr$^{\circ}$ s. Carol Sonenreich e Giordano Estevão, pelo espaço de exercício e respeito pela diversidade de raciocínios clínicos no Serviço de Psiquiatria do Hospital do Servidor Público Estadual.

À Dra. Kátia da Silva Wanderley, chefe da Seção de Psicologia do Hospital do Servidor Público Estadual, por seu exemplo profissional, pela flexibilidade com que sempre acolheu meus pedidos e, principalmente, pela amizade que cultivamos.

À Profa. Maria Tereza Viscarri Montserrat, parceira no trabalho com grupos e companheira de diferentes experiências grupais, por tolerar minhas aflições e pelos delicados comentários.

À Berenice Neri Blanes, pela atenciosa leitura do projeto e, por desde sempre, de modo muito generoso, me indicar os melhores caminhos a serem percorridos. 
À Celina Giacomelli, por ter se disponibilizado a acompanhar-me no árduo trajeto da análise pessoal.

Aos professores do Departamento Formação em Psicanálise do Instituto Sedes Sapientiae, pela transmissão do pensamento psicanalítico.

Às minhas queridas irmãs: Marisa Aparecida Bento e Márcia Bento. A primeira pela revisão deste trabalho, sempre disponível para a correção dos meus erros. A segunda, por me substituir nos cuidados familiares, quando necessário. E, principalmente, por estarem sempre presentes.

À Célia Maria Amato Balian, amiga de todas as horas, por sua presença nos momentos importantes da minha vida.

Ao Eduardo Berbery, pela gentileza de seus gestos e palavras e pela intensa e carinhosa estadia em minha vida.

À Rogéria Coutinho Brandani, pela paciência com minha ausência e ajuda nas tarefas que não pude dar conta.

Aos colegas da Seção de Psicologia do Hospital do Servidor Público Estadual, espaço do exercício prático da grupabilidade.

Aos pacientes da Seção de Psicologia do Hospital do Servidor Público Estadual, por serem meus pacientes e por me proporcionarem essa experiência.

A todas as pessoas que estiveram de algum modo com "as mãos" neste trabalho, quer seja lendo, corrigindo, imprimindo, quer seja encadernando, marcando datas, enfim... 
"O valor das coisas não está no tempo que elas duram, mas na intensidade com que acontecem.

Por isso existem momentos inesqueciveis, Coisas inexplicáveis e pessoas incomparáveis".

Fernando Pessoa 


\section{SUMÁRIO}

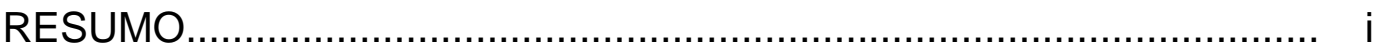

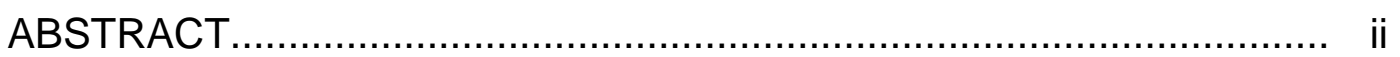

APRESENTAÇÃO ................................................................. iii

1. INTRODUÇÃO ............................................................... 1

2. FREUD E A CONSTITUIÇÃO DO SUJEITO PSÍQUICO.................. 5

2.1 O sujeito e o outro: narcisismo e alteridade................... 5

2.2 Considerações sobre o conceito de objeto em psicanálise 12

2.30 mal-estar compartilhado: do sujeito ao grupo.............. 16

3. PSICANÁLISE, GRUPOS E INSTITUIÇÕES............................. 20

3.1 Histórico das configurações vinculares........................... 20

3.2 A contribuição de René Kaës................................... 24

3.3 Alguns conceitos fundamentais: $o$ negativo e $o$ intermediário

3.4 Novos dilemas técnicos ou velhos conhecidos reeditados?

4 DELIMITAÇÃO DO MÉTODO 39

4.1 Pesquisa em psicanálise. 39

4.2 Contextualização da instituição de saúde........................ 43

4.3 A instituição como objeto intra e intersubjetivo................. 49

5 DISCUSSÃO DO MATERIAL CLÍNICO............................... 54

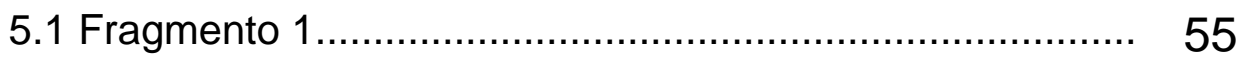

5.2 Fragmento 2 .................................................. 50

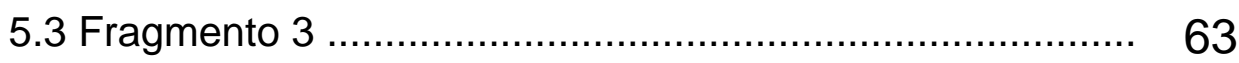

5.4 Importância dos grupos na atualidade........................... 66

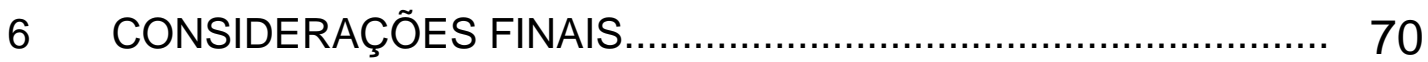

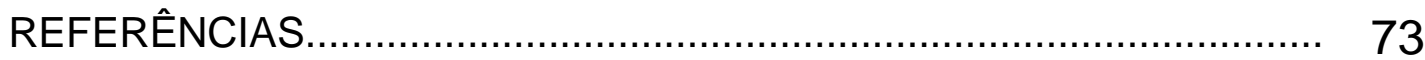


BENTO, M. Grupos terapêuticos em instituição de saúde: a relação entre a intersubjetividade e o intrapsíquico na Psicanálise. 2006. 80 f. Dissertação (Mestrado) - Instituto de Psicologia, Universidade de São Paulo, São Paulo, 2006.

Este trabalho apresenta o resultado de questionamentos sobre o atendimento clínico contextualizado em Instituição de Saúde. Tem por objetivo pesquisar as bases teóricas dos grupos terapêuticos, analisar e explicitar os fatores que fundamentam os grupos como campo de intervenções terapêuticas, por meio do estudo de grupos, especificamente dos grupos terapêuticos.

A pesquisa é sustentada no referencial psicanalítico, cujo objeto de estudo é o Inconsciente e o eixo clínico está apoiado no conceito de transferência.

O eixo teórico fundamental é a constituição da subjetividade e suas relações com a intersubjetividade, conceitos que são abrangidos em um estudo longitudinal no pensamento freudiano. Outro eixo, é o esclarecimento das fontes epistemológicas de grupos, especificamente as do campo da psicanálise, abordadas por meio de autores contemporâneos, visando à compreensão da noção de intersubjetividade e dos fenômenos grupais. O conteúdo teórico desenvolvido é ilustrado por dados obtidos de recortes do material clínico dos atendimentos de grupos terapêuticos realizados no Hospital do Servidor Público Estadual "Francisco Morato de Oliveira". Este estudo demonstra que as relações do sujeito psíquico com o outro semelhante podem propiciar alterações intrapsíquicas que contribuem para o tratamento do sofrimento humano.

Palavras-chave: Psicanálise. Grupo Terapêutico. Subjetividade. 
BENTO, M. Therapeutic Groups in the context of a health institution: the relationship between intersubjectivity and intrapsychic in the Psychoanalysis.

This work presents the results of an inquiry on the clinic services in the context of a health institution. Its aim is to research the theoretical basis of the therapeutic groups, analyse and explicit the factors that establish the group as a field of therapeutic intervention through the study of these groups, specifically the therapeutic ones.

The research is founded on the psychoanalytical referential whose object of study is the unconscious where the clinical axis is supported on the transfer concept.

The fundamental theoretical axis is the constitution of the subjectivity and its relationship with intersubjectivity, concepts embodied in a longitudinal study of the Freudian thinking. Another axis is the clarifying of the epistemological sources of the groups, specifically those of the psycoanalytical science, focused through the contemporary authors, seeking the comprehension of the notion of intersubjectivity and group phenomena. The theoretical content developed is illustrated by data extracted from cut-outs of clinic materials collected in the day-to-day practice of the therapeutical teams of the State Public Hospital "Francisco Morato de Oliveira".

This study demonstrates that the relationship of the psychic subject with the other may bring on intrapsychic changes that contribute to the treatment of the human suffering.

Keywords: Psychoanalysis. Therapeutic group. Subjectivity. 
Este trabalho tem origem na experiência pessoal da autora com os grupos terapêuticos atendidos no ambulatório da Seção de Psicologia do Instituto de Assistência Médica ao Servidor Público Estadual - Hospital do Servidor Público Estadual - Francisco Morato Oliveira (HSPE - FMO), durante o período de 1994 até 2003.

A psicoterapia de grupo tem sido uma das técnicas mais utilizadas no atendimento aos pacientes ambulatoriais, e a prática clínica foi estabelecendo insistentemente algumas questões:

a) a demanda institucional, por vezes, provoca a tendência grupalista, que encobre as carências institucionais e desmerece a prática dessa modalidade de atendimento;

b) a exigência resultante da demanda pode contribuir com o desaparecimento do campo necessário para a produção da subjetividade e criar lugar para as pseudo-resoluções, em que o atendimento de grupo, eventualmente, pode ser uma das pseudo-resoluções;

c) o real psíquico é atravessado pelo real social e a intersubjetividade pode ser forte via de acesso terapêutico, se indicada e conduzida de forma precisa. 
Por conseguinte, manifestou-se o interesse em realizar um estudo sobre o modo de o grupo se oferecer como espaço, para que surjam as transferências e as manifestações regressivas que autorizam as formações grupais a serem campo de operações terapêuticas.

O referencial teórico, em que está apoiada a pesquisa bibliográfica, é proveniente da Psicanálise, que delimita o campo subjetivo e tem como objeto de estudo o Inconsciente.

A psicoterapia de grupo, muitas vezes, é apreendida como uma técnica capaz de resolver apenas a demanda dos pacientes em uma Instituição e, por outro lado, também como um meio de atingir metas quantitativas.

Especificamente no campo da psicanálise, a psicoterapia de grupo, durante muitos anos, ocupou o lugar de aplicação dos conceitos psicanalíticos, sendo alvo de muitos questionamentos, na medida em que seu dispositivo de cura o grupo - não corresponde ao setting necessário para se dar o referido tratamento.

Entendemos que deste modo desmerecemos uma importante prática clínica, reduzindo-a a um modo de apresentar pseudo-resoluções à demanda institucional.

Compreendemos também, que a chamada psicanálise aplicada, se refere à aplicação de conceitos psicanalíticos na análise de objetos inanimados, que não associam livremente, não estabelecem relações transferenciais e nem se modificam mediante interpretações.

Desse modo, questionaremos estas acepções da psicoterapia de grupo e, recorreremos a autores contemporâneos para sustentar e discutir os problemas epistemológicos e metodológicos que irão se interpor no decorrer deste trabalho. 
Também não temos como meta reduzir a prática da psicanálise às relações intersubjetivas, quer sejam nos grupos, na família ou nas Instituições; mas sim, confirmações do grupo como objeto e campo de práticas terapêuticas. Ou seja, valorizar a dimensão do grupo como lugar intermediário entre o individual e o coletivo e como espaço transicional entre o intrapsíquico e o intersubjetivo.

Assim, delineada essa demanda, faz-se necessário uma revisão do conceito de Grupo dentro do campo da Psicanálise. Para tanto, primeiramente seguimos uma trajetória na obra freudiana, recorrendo a conceitos metapsicológicos que deram sustentação ao desenvolvimento da chamada Psicanálise das Configurações Vinculares. Posteriormente, apresentamos autores psicanalíticos contemporâneos que desenvolveram conceitos os quais permitem ao dispositivo grupal constituir-se também como um meio de captura do inconsciente. Deste modo, os grupos terapêuticos deixam de ser o lugar de informação ou de vazão institucional para ser um espaço de mudanças psíquicas em face da intersubjetividade.

A inquietação que produziu todo este estudo teve sua origem na prática clínica desenvolvida em uma instituição de saúde, mais especificamente um hospital geral que oferece ao público atendido o serviço de psicologia.

Portanto, fez-se necessário abordar o modo como as instituições são inscritas no universo psíquico, além de delimitar o conceito.

Finalmente, faremos uma incursão sobre o atendimento grupal e sua importância na atualidade, levando em consideração as características da constituição da subjetividade contemporânea. 
A hipótese que sustenta este trabalho reside no estudo das relações humanas e na capacidade que essas relações têm de operar mudanças nos arranjos intrapsíquicos do sujeito.

Por conseguinte, este estudo é o relato desta experiência e da busca de respostas que conciliassem a vivência clínica e a abordagem teórica. Do mesmo modo, os recortes e vinhetas clínicas de intervenções grupais aqui utilizados têm como objetivo explicitar, ilustrar e articular o campo teórico com o campo clínico. 
Entre os autores clássicos é consenso a origem da Psicoterapia de Grupo: foi em 1905, nos Estados Unidos, com os estudos do médico Pratt, no Hospital John Hopkins. Este médico, utilizando-se de conhecimentos pedagógicos, constatou que seus doentes tuberculosos reagiam melhor aos seus cuidados médicos, quando participavam de reuniões grupais com outros pacientes. Desde então, inúmeros autores, de diferentes orientações teóricas, desenvolveram conceitos teóricos a partir da clínica com grupos, a fim de sistematizar a técnica de grupo.

Atualmente, as psicoterapias de grupo expandiram-se, existindo muitos grupos e escolas com diferentes objetivos e orientações terapêuticas. Conseqüentemente, observamos uma confusão conceitual e um campo de difícil delimitação. Além disso, a prática da psicoterapia de grupo também está sob a influência de muitas disciplinas, tais como: a psiquiatria, a psicologia, a sociologia, a educação, entre outras.

Em que pese todo esse conceitual enredado, o desenvolvimento da nova conceitualização foi fundamentado em premissas básicas das postulações freudianas. Sendo assim, deteremo-nos no estudo das relações entre a psicanálise e o grupo, esperando desse modo circunscrever o campo conceitual.

As fontes epistemológicas dos grupos são extremamente intrincadas. Podemos afirmar que existe, no mínimo, uma base psicanalítica filosoficamente tão diversificada quanto às próprias escolas psicanalíticas. 
Autores psicanalíticos contemporâneos ocuparam-se na tentativa de compreender e aplicar os principais conceitos da psicanálise às formações grupais. Assinalamos alguns deles e suas filiações:

a) linha inglesa: Bion, Ezriel, Foulkes, Balint;

b) linha americana: Schilder, Taylor, Bach;

c) linha francesa: Anzieu, Kaës;

d) linha argentina: Grinberg, Langer, Rodrigué, Bleger, PichonRiviére, Berenstein.

Portanto, podemos afirmar que não existe nenhuma tendência que não tenha incorporado elementos teóricos ou técnicos de outras (Baremblitt, Guatarri \& Leitão, 1986).

Faz-se necessário então diferenciar o estudo dos pequenos grupos, que este trabalho enfoca, dos fenômenos de massa ou dos grupos de finalidades não terapêuticas.

O estudo de grupos compreende o estudo do sujeito singular na sua capacidade de estar junto e de compartilhar, mantendo sua alteridade frente ao objeto e assim garantindo a saída de um estado narcísico e onipotente.

Uma vez estabelecidas essas definições, o estudo precisa desvelar o conceito de objeto em psicanálise, na medida em que o outro semelhante é vivenciado psiquicamente como um objeto. Nessa relação, muitas vezes o outro se torna um depositário de questões intrapsíquicas. Partindo-se dessa premissa, temos configurado o campo terapêutico despertado no contato e apreendido pela escuta analítica. 
Não podemos nos furtar de analisar o fato de que os grupos aqui estudados estão inseridos em uma Instituição - o Hospital do Servidor Público Estadual -, portanto, os sujeitos ali reunidos mantêm com a instituição uma relação transferêncial sujeita a ser depositária de expectativas.

Freud (1921/1987I), no texto "Psicologia de grupo e a análise do ego" , faz uma interpretação das formações grupais, utilizando como modelo dois grupos artificiais: a Igreja e o Exército. Porém, é consenso que o objetivo de Freud, neste e em outros textos que aborda os grupos, as massas e a cultura, sempre foi o estudo dos fenômenos psíquicos no campo social e nunca uma proposta terapêutica. Essa última surge como uma necessidade premente, a partir do momento que a prática da psicanálise extrapola os limites do consultório privado e se insere em Instituições.

A exemplo desse texto supracitado, outros textos freudianos são referência para autores que desenvolveram o tema dos grupos na psicanálise, a saber: "Sobre o narcisismo: uma introdução" (1914/1987f), oferece a compreensão sobre o campo intersubjetivo e sobre sua importância na constituição do sujeito da psicanálise; "Totem e tabu" (1913/1987e); “O futuro de uma ilusão" (1927/1987o); “O mal-estar na civilização" (1930/1987p); "Moisés e o monoteísmo" (1939/1987q). Todos esses textos articulam as relações dos sujeitos na civilização, no social e com as instituições.

W. R. Bion, durante a década de 1940, já membro da Sociedade Britânica de Psicanálise, deu a primeira e uma das mais importantes contribuições para o trabalho grupal, reunidas na obra "Experiências com grupos" (Bion, 1948/1975), enfrentando na época a desaprovação da comunidade psicanalítica. Com base em suas experiências com grupos de soldados realizadas no Hospital Northfield, Inglaterra, durante a Segunda Guerra Mundial, Bion levantou hipóteses 
sobre o campo grupal e criou um corpo conceitual até hoje estudado. Os trabalhos de Bion deram origem ao grupo como uma entidade que pode ser pensada através dos conceitos psicanalíticos e experimentados em uma situação apropriada. Assim, observamos que, tal como em qualquer campo da psicanálise, a prática clínica está intimamente vinculada à evolução dos conceitos.

Posteriormente, observamos a manifestação de uma nova corrente constituída pelas contribuições de S.-H. Foulkes, J. Rickman e H. Ezriel, denominada Grupoanálise.

O outro grande grupo de modelos pós-freudianos está ligado ao movimento psicanalítico da escola francesa, cujos expoentes são D. Anzieu e R. Kaës.

Cada qual são diferenciados por bases teóricas e metodológicas sensivelmente diferentes. De modo geral são denominadas Psicanálise das Configurações Vinculares ou Psicanálise Vincular, por trabalharem no âmbito dos grupos, das famílias, dos casais e das Instituições.

Podemos observar que, na contemporaneidade, as modalidades de grupo foram mais desenvolvidas por teóricos provenientes de países como a França e a Argentina. Tal fato não se deu aleatoriamente, pode ser compreendido historicamente, tanto no tocante à história e às influências do movimento psicanalítico nesses países, quanto ao movimento político e social. 


\section{FREUD E A CONSTITUIÇÃO DO SUJEITO PSÍQUICO}

2.1 O sujeito e o outro: narcisismo e alteridade

Desde o nascimento, a criança tem como característica fundamental algo que podemos denominar como dependência originária do outro, ou seja, se alguém de seus semelhantes não cuidar de suas necessidades básicas, como a fome ou o frio, ela não dispõe de recursos internos ou externos para sobreviver. Esse é o protótipo da situação traumática geradora de angústia, da qual decorre o conceito de desamparo: é um estado inicial do sujeito, correlativo à dependência da mãe para a sobrevivência, que pode ser disparado novamente por situações extremas.

Os cuidados primários são desempenhados pela mãe ou, na sua ausência, por um substituto que desempenhe essa função de maternagem.

O amor dos pais, tão comovedor e no fundo tão infantil, nada mais é senão o narcisismo dos pais renascido, o qual, transformado em amor objetal, inequivocamente revela sua natureza anterior (Freud, 1914/1987f, p. 108). 
Essa condição inerente à situação do ser humano recém-nascido é, para a psicanálise, o início de sua constituição subjetiva, de seu mundo interior, denominado intrapsíquico; e a isso se convencionou chamar realidade psíquica. Do ponto de vista psicanalítico, observamos que é constitutivo do tornar-se humano a função do outro na determinação desse sujeito, que será sujeitado ao seu inconsciente fundado nessas relações primárias. Assim, concluímos que o campo psíquico se constitui, em parte, pela grupabilidade e, em parte, pela corporeidade. $\mathrm{O}$ sujeito do inconsciente é um sujeito de um grupo que o constituiu.

Em "Projeto para uma psicologia científica", Freud (1895/1987a) define que o objeto da vivência de satisfação - no caso o seio da mãe - realiza uma função específica que deixa no sujeito um triplo registro:

a) o mnêmico da vivência de satisfação;

b) o dos movimentos que acompanharam o ato e o registro da descarga;

c) o prazer concomitante.

Diante da reaparição da necessidade e do desejo, o registro do objeto é reativado e alucinado. Dessa forma, pela primeira vez, contrapõe-se ao ego, um "objeto" como algo que se encontra "fora", e somente mediante uma ação peculiar do bebê (o choro) é forçado a aparecer (Freud, 1930/1987p).

Isto realça a importância da realidade externa antes e depois do aparecimento do sujeito, a qual, unida ao conceito de desamparo original do ser humano, será a fonte primordial da cultura ("motivações morais", diz Freud) (Baranger et al., 1994, p. 5). 
Cabe então discutirmos a importância dessa percepção de um outro que não é o si mesmo e que será tomado como um objeto de prazer, como alvo de identificações e que terá desdobramentos durante a infância. Para tanto, começaremos por discorrer sobre o narcisismo, um estado precoce, em que o eu será tomado como um objeto de amor, após ter se operado a identificação primária.

Discutir o conceito de narcisismo neste momento se torna fundamental, pois permite interpretar a importância do outro na constituição do intrapsíquico, proporcionando a abertura do campo das relações intersubjetivas e as possibilidades da constituição de uma estrutura psíquica em que se permitem a grupabilidade e os vínculos intersubjetivos. Além disso, o conceito de narcisismo se encontra cunhado em um momento histórico decisivo da psicanálise, a saber: na articulação entre as duas teorias tópicas e as duas teorias pulsionais.

O termo narcisismo surge em sua plenitude na obra freudiana em 1914 (Freud, 1914/1987f), em virtude da necessidade de possibilitar a inclusão das manifestações psicóticas no campo psicanalítico, e a teoria da libido desenvolvida até então não permitia essa reflexão.

Narcisismo, neste texto, é definido como o complemento libidinal do egoísmo da pulsão de autoconservação, ou seja, essa pulsão recebe uma intensidade a mais, advinda do estabelecimento de uma pulsão sexual, tendo esta última o eu do sujeito como objeto. Para Freud, existe uma fase narcísica no desenvolvimento do ser humano, precedida pela fase de auto-erotismo e anterior à escolha de objeto. O narcisismo pode então ser compreendido como um destino possível para a libido, bem como sua função, em princípio, é a de organizar as pulsões parciais, dirigindo-as ao eu. 
O ego é, primeiro e acima de tudo, um ego corporal; não é simplesmente uma entidade de superfície, mas é, ele próprio, a projeção de uma superfície (Freud, 1923/1987m, p. 40).

O conceito de narcisismo está estreitamente vinculado à progressão da libido em relação a um objeto. Está precedido pelo auto-erotismo - estado anárquico pulsional - e é anterior à escolha de objeto. Assim, a constituição do eu é uma ação psíquica que organizará as pulsões em torno dele, o que o promoverá a um objeto interno.

A definição corresponderia ao chamado narcisismo primário, uma concentração de libido dentro do eu. Posteriormente, na vida do sujeito, quando a libido antes dirigida para os objetos externos se retrai para o ego (então já constituído), fala-se em narcisismo secundário. Desse modo, o conceito de narcisismo reformula o conceito de objeto em psicanálise: a idéia de que só haverá objeto após a fase de escolha objetal deixa de ter sentido, uma vez que há escolha de objeto na fase narcísica, o objeto é o próprio eu, o objeto da fase subseqüente será um objeto externo, escolha que se dará com os desdobramentos do complexo de Édipo.

A postulação do narcisismo coloca em evidência a impossibilidade de sustentar o dualismo pulsional - fundamental para o pilar básico da psicanálise que é a noção de conflito - em pulsões de autoconservação e pulsões sexuais, que Freud, posteriormente (na sua segunda teoria tópica do aparelho psíquico), altera para pulsão de vida e pulsão de morte. O conceito de narcisismo aponta para uma retração da libido que não se liga a objetos, noção essa abarcada pelo conceito de pulsão de morte - ruptura, disjunção da energia psíquica em relação a seus representantes. 
O processo do narcisismo - retração da libido para o ego - faz parte de vários contextos, nem sempre indicativos de patologia, por exemplo, o luto pela perda de um objeto amado. O narcisismo é um estado constitutivo do sujeito, caracterizado por um processo identificatório definido pelo retorno narcisista da escolha objetal. Desse modo, Freud aponta para a dinâmica, a mobilidade e a qualidade do processo como os indicativos, ou não, daquilo que se convencionava chamar de anormalidade.

Outro ponto decisivo neste texto (Freud, 1914/1987f) é a consideração da existência permanente, simultânea e proporcional de uma oposição entre a libido do eu e a libido do objeto.

A escolha de objeto secundária ao complexo de Édipo será marcada por esses objetos primários, mas a partir de um prisma de uma relação intersubjetiva, pois a sexualidade será a responsável por tal vinculação. Assim, a escolha de objeto conduz a um sentimento de não eu, o qual, por definição, distancia-se do narcisismo e obriga uma parte do sujeito perceber - ao menos potencialmente - essas diferenças.

A esse reconhecimento do outro segue a experiência do estranho (unheimlich), não é somente o novo que produz medo, mas sim o desconhecido que existe dentro do conhecido (Freud, 1919/1987i). Desde aí decorre o que Freud denominou narcisismo das pequenas diferenças: quando não se pode reconhecer o outro como semelhante, o outro é investido como estranho absoluto, objeto de ódio e de movimentos de destruição, quer seja por anulação, exclusão, quer por incorporação devoradora. Esta é, portanto, a faceta social do conceito de narcisismo, a ponte na qual este conceito transita para a cultura. 
Ao ego ideal do narcisismo infantil vem se opor o ideal de ego, instância constituída a partir das figuras parentais e que será depositário das ilusões narcísicas já transformadas pela experiência de castração advinda dos desdobramentos edípicos. O ideal de ego deixa evidente a divisão do sujeito e sua dependência do outro, na medida em que se abandona o narcisismo infantil e se opta por objetos de identificação do id.

Pode ser que essa identificação seja a única condição em que o id pode abandonar os seus objetos (...) e torna possível supor que o caráter do ego é um precipitado de catexias objetais abandonadas e que ele contém a história dessas escolhas de objeto (...) pode-se dizer que essa transformação de uma escolha objetal erótica numa alteração do ego constitui também um método pelo qual o ego pode obter controle sobre o id, e aprofundar suas relações com ele - à custa, é verdade de sujeitar-se em grande parte às exigências do id. Quando o ego assume as características do objeto, ele está-se forçando, por assim dizer, ao id como um objeto de amor e tentando compensar a perda do id ... (Freud, 1923/1987m, pp. 43 - 44).

Podemos dizer que o narcisismo infantil não é totalmente superado, mas sim transformado. Mesmo sendo a escolha de objeto o destino final da libido, isto não supõe necessariamente o abandono do narcisismo.

O narcisismo infantil desdobra-se em estruturas que farão parte do aparelho psíquico, são elas: eu ideal e ideal de eu. O ideal de eu se revelará em fenômenos típicos das formações culturais e grupais, evidenciando as raízes narcisistas dos mesmos.

Freud (1914/1987f) nos esclarece que a formação de um ideal é um fator condicionante do recalque das moções pulsionais e as representações éticas e culturais são as motivações para tal recalque.

A cultura é parte integrante da subjetividade, quer seja constitutiva, quer seja um meio em que a pulsão encontra os seus objetos de satisfação. Mas, 
justamente por esse mesmo motivo, é o lugar onde nos defrontamos com as manifestações pulsionais dos outros (Kehl, 2000).

Alteridade é definida no "Dicionário Houaiss da língua portuguesa" do seguinte modo:

...2.Rubrica:filosofia.

situação, estado ou qualidade que se constitui através de relações de contraste, distinção, diferença [Relegada ao plano de realidade não essencial pela metafísica antiga, a alteridade adquire centralidade e relevância ontológica na filosofia moderna (hegelianismo) e esp. na contemporânea (pós-estruturalismo).] (Houaiss, 2005).

Podemos observar que o fato da noção de alteridade adquirir importância na filosofia moderna e, especialmente, na contemporânea, vem ao encontro da concepção das sociedades que cultuam os ideais narcísicos em detrimento do reconhecimento da diferença, do outro e da própria finitude.

Segundo a análise de Kehl (2000), a função fraterna desempenhada pelo semelhante deve ser considerada em três pontos de abstração: primeiro, a constatação para a criança da semelhança na diferença em seu campo narcísico; segundo as experiências compartilhadas pela fratria na adolescência, uma espécie de reedição do primeiro; e, finalmente, a abertura de um campo anônimo de circulação e transmissão de saberes. Esse campo, que só pôde existir em função dos anteriores, é o que estaremos enfocando nos trabalhos com grupos, por meio dos efeitos da intersubjetividade no intrapsíquico. 
2.2 Considerações sobre o conceito de objeto em psicanálise

As concepções teóricas da psicanálise introduzem uma ruptura epistemológica com o saber e a prática da medicina, da filosofia e da psicologia, na medida em que modificam a posição do objeto. Assim, para a psicanálise, objeto é considerado sob o aspecto daquele em que é investido pela pulsão e pela fantasia do sujeito.

A necessidade de se discutir tal tópico decorre do fato de que nos grupos terapêuticos a problemática central se refere à relação dentro / fora. Essa problemática pode ser desdobrada na dualidade eu / não eu (outro).

O conceito de objeto adquire no pensamento freudiano múltiplas origens e os desdobramentos posteriores do tema são diversos. Além disso, a noção de objeto adquire conceitualização diversa nas diferentes orientações teóricas.

Outro obstáculo consiste no fato de que existem inúmeros conceitos interligados ao de objeto e que, por vezes, são imprescindíveis para a apreensão do termo. Porém, não temos por objetivo uma revisão bibliográfica do conceito, o que nos obrigará a efetuar recortes compatíveis com o tema ora desenvolvido.

No "Vocabulário da psicanálise" (Laplanche \& Pontalis, 1986), o verbete objeto esclarece que a noção de objeto é encarada em psicanálise sob três aspectos principais:

a) enquanto alvo correlativo da satisfação pulsional, podendo se tratar de um objeto parcial, de um objeto real ou de um objeto fantasmático; 
b) enquanto correlativo do amor ou do ódio, sendo a relação em causa total e o adjetivo correspondente objetal e, finalmente,

c) no sentido tradicional da filosofia e da psicologia, enquanto correlativo do sujeito que percebe e conhece.

Lembremos que, conforme explicitado, a discriminação do eu se dá como um processo de diferenciação do outro e que o próprio eu pode ser tomado como um objeto interno. Portanto, o papel do objeto se torna imperativo e articulado com a definição de sujeito na psicanálise.

Baranger et al. (1994), que faz um levantamento do conceito na obra freudiana, propõe distinguir diferentes direções:

a) objeto como objeto da pulsão, tal como é descrito nos Três ensaios da teoria da sexualidade;

b) objeto em relação ao narcisismo, ou seja, o próprio ego como objeto da pulsão, tal como exposto em Sobre o narcisismo: uma introdução;

c) objeto em relação à identificação, ou seja, objeto que pode existir dentro do sujeito após seu desaparecimento real, tal como desenvolvido em Luto e melancolia.

A última linha de pensamento adquire cada vez mais importância para Freud e a qual se torna fiel até o final de sua obra. Observa-se que a ênfase deixa de ser da ordem da representação - relação de objeto - para se tornar da ordem da estrutura psíquica, o que equivale a dar ao objeto um estatuto interno estruturante do sujeito e das relações intersubjetivas e não meramente representacional. 
Em "Os três ensaios sobre a teoria da sexualidade", Freud (1905/1987b) define desde o início o objeto como objeto da pulsão, mas a pulsão não é determinada pela presença do objeto. Em outras palavras, a pulsão preexiste ao objeto, na medida em que sua origem está entre o somático e o psíquico.

Em "Os instintos e suas vicissitudes", Freud (1915/1987g) afirma que:

A finalidade pela qual cada um deles luta [os instintos ou pulsões] é a consecução do 'prazer do órgão' (...). Logo que surgem, estão ligados aos instintos da autopreservação, dos quais só gradativamente se separam; também na sua escolha objetal, seguem os caminhos indicados pelos instintos do ego (Freud, 1915/1987g, pp. 146-147).

Já assinalamos que Freud articula o surgimento da pulsão sexual apoiada na pulsão de autoconservação e a teoria da libido dará dinamismo às relações sujeito / objeto.

O objeto mantém com o sujeito diversas ordens de relação. Enquanto objeto da percepção, trata-se de um objeto externo e real, captado pelo sujeito e capaz de ser acessível a ele. O objeto é também o objeto do desejo, ou seja, objeto da pulsão, a fim da satisfação pulsional; e, finalmente, o objeto será mnêmicamente fixado, produzindo uma representação do objeto no sujeito. A partir de então, o objeto assume o estatuto de objeto interno.

O grupo enquanto objeto é, como qualquer outro objeto, constituído pelos investimentos libidinais e representado psiquicamente pelo sujeito.

As relações e os investimentos, que são dirigidos de um sujeito aos grupos aos quais pertence, são desdobramentos dos investimentos nos grupos internalizados. Estes grupos são originados nas primeiras experiências em grupos de pertencimento, tais como as famílias. 
Depois da Segunda Guerra Mundial, a análise das relações objetais deixou de visar unicamente à realidade psíquica ou fantasmática estendendo-se ao estudo de todas as formas de ambiente. A ampliação do âmbito da expressão relação objetal acompanhou a expansão da própria psicanálise, tratando de compreender as modalidades de inserção do eu na cultura (Roudinesco \& Plon, 1998). 
2.3 O mal-estar compartilhado: do sujeito ao grupo

Conforme citado anteriormente, certamente Freud não esboçou nenhuma prática clínica com grupos. Textos como "Totem e tabu", "Psicologia das massas e análise do ego" (1), "O futuro de uma ilusão", "O mal-estar na civilização" e "Moisés e o monoteísmo" têm por objetivo estudar a cultura, a civilização (2), as massas, a sociedade, a coletividade. Somente em "Psicologia das massas e a análise do ego", Freud (1921/1987l) faz um breve esboço do pequeno grupo. Todas as teorias psicanalíticas contemporâneas sobre grupo são construções e inferências a partir desses textos freudianos, por isso sua importância.

Como já é possível observar, a questão objeto é imensa e não temos nenhuma pretensão de esgotar os vértices possíveis do pensamento social freudiano. Assim, teremos que optar por fazer alguns recortes na obra, bem como deixar de lado inúmeros trabalhos que tematizaram a questão, quer seja dentro quer seja fora da psicanálise.

Em "Totem e tabu", Freud (1913/1987e) descreve os interditos fundamentais que são a proibição do incesto, a interdição de matar o animal totêmico e o irmão. Apresenta como tese central a idéia de que a civilização surge de um assassinato cometido em conjunto - o assassinato do pai.

(1) A tradução grupo para o termo original Massenpsychologie é infeliz, por isso optamos por manter o termo "massas".

(2) Tal como apontado por todos os autores contemporâneos e tradutores das obras freudianas, não distinguimos civilização e cultura, pois Freud usava os termos como sinônimos. 
Segundo Lévi-Strauss (1949) apud Garcia-Roza (1995), a proibição do incesto é uma regra estritamente social, embora possua a universalidade do que é natural. Essa característica faz da proibição do incesto o lugar privilegiado da passagem da natureza para a cultura.

$\mathrm{Na}$ horda primeva, conta Freud, havia um pai violento e ciumento (...). Um dia, os irmãos expulsos retornaram juntos, mataram e devoraram o pai. $O$ que individualmente era impossível tornou-se possível graças a união (...). Devorando-o, realizaram a identificação com ele, cada um adquirindo parte de sua força. Mas, após o assassinato, surgiu o sentimento de culpa, e o pai morto tornou-se mais forte do que vivo. O que então fora proibido pela existência real do pai, passou a ser proibido pelos próprios filhos (...). Com isto, criaram os dois tabus fundamentais do totemismo, os quais correspondem aos dois desejos recalcados do complexo de Édipo: o parricídio e o incesto (Garcia-Roza, 1995, p. 27).

Este é o resumo dos temas apresentados no texto de Freud e uma imagem fiel dos interditos que regulam as relações entre os semelhantes. Observamos aqui presente a idéia de que a civilização tem por meta auxiliar o sujeito no gerenciamento de sua agressividade e de seu narcisismo.

Em "O futuro de uma ilusão", Freud (1927/1987o) toma como padrão do funcionamento cultural a religião. Postula que a civilização precisa oferecer algum consolo, para que o homem possa abrir mão de sua liberdade instintiva. Essas compensações seriam de três tipos: o narcisismo das pequenas diferenças, a religião (ambas saídas neuróticas para Freud) e a arte. Neste texto a concepção de civilização já está acrescida de mais um componente: o desamparo do homem. Até então, o nascimento da civilização era compreendido para controlar as pulsões sexuais e o ímpeto narcísico (Costa, 1989).

O sofrimento nos ameaça a partir de três direções: de nosso próprio corpo, condenado à decadência e à dissolução, e que nem mesmo pode dispensar o 
sofrimento e a ansiedade como sinais de advertência; do mundo externo, que pode voltar-se contra nós com forças de destruição esmagadoras e impiedosas; e, finalmente, de nossos relacionamentos com os outros homens. O sofrimento que provém dessa última fonte talvez nos seja mais penoso do que qualquer outro (Freud, 1930/1987p, p. 95).

Em "O mal-estar na civilização", Freud (1930/1987p) se mostra desapontado com os ideais civilizatórios, e também reafirma a tensão permanente existente entre a natureza e a cultura. Apega-se significativamente ao conceito de desamparo, sinal da fragilidade humana.

Lembremos também que esses textos foram escritos por Freud em um período pós-guerra, que muito o influenciou, e em época que sofria com os malestares de sua doença. Freud desqualificou esses seus dois últimos textos com uma autocrítica impiedosa, tal como fizera antes com "A interpretação dos sonhos" (Gay, 1989).

No texto "Psicologia das massas e a análise do ego", Freud (1921/1987l) parte do pressuposto que as relações de um sujeito com seus pais, com os irmãos, com o objeto de seu amor e com seu médico, consideradas até então pela psicanálise, poderiam reivindicar a posição de fenômenos sociais e poderiam ser colocadas em discussão em comparação com outros processos, nos quais a satisfação pulsional é alcançada sob a influência de outras pessoas. Para tanto, analisa dois exemplos de fenômenos de massa, a Igreja e o Exército, apontando que toda estrutura de sustentação desses grupos está nos vínculos que unem cada membro ao líder. Podemos compreender essa função do líder como uma espécie de reedição do pai da horda.

Ainda como contribuição fundamental de "Psicologia das massas e a análise do ego" (1921/1987I), podemos citar o capitulo VII que se desenvolve sob o tema da identificação, definida como a mais remota expressão de um laço emocional 
com outra pessoa. A identificação remonta ao complexo de Édipo e mostra-se desde o princípio com o caráter ambivalente de amor e ódio. É diferenciada da escolha de objeto e aponta o fato que a identificação é um mecanismo no qual o ego se esforça para se moldar, conforme o aspecto daquele que foi tomado como modelo. Distingui ainda três modalidades de identificação: primária, secundária e histérica.

Podemos observar que a identificação mantém então estreito laço com a questão narcísica, na medida em que apenas nos identificamos com aquilo que de algum modo nos satisfaz narcisicamente. A identificação é um modo de transformar a libido que está investida nos objetos em libido narcisista.

Freud (1921/1987l) em sua teoria sobre as massas faz uma passagem direta da massa para o sujeito intrapsíquico - objeto de seu interesse. Porém, com isto a dimensão do grupo, enquanto dispositivo de cura, foi deixada de lado. Por esse motivo, o estudo dos grupos é compreendido como o elo que dará maior sentido para a compreensão da passagem do coletivo para o singular, do público para o privado. É no grupo e no sentimento de pertencimento a um grupo que se dá a passagem do individual para o social em uma cultura.

... apenas raramente e sob certas condições excepcionais, a psicologia individual se acha em posição de desprezar as relações desse indivíduo com os outros. Algo mais está invariavelmente envolvido na vida mental do indivíduo, como um modelo, um objeto, um auxiliar, um oponente, de maneira que, desde o começo, a psicologia individual, nesse sentido ampliado mas inteiramente justificável das palavras, é, ao mesmo tempo, também psicologia social (...). E, realmente, é em apenas algumas questões que a psicologia profunda da psicanálise está especialmente interessada (Freud, 1921/1987I, p. 91). 


\section{PSICANÁLISE, GRUPOS E INSTITUIÇÕES}

\subsection{Histórico das configurações vinculares}

O desafio colocado neste tópico se refere ao fato das inúmeras correntes psicanalíticas que desenvolveram o tema dos grupos. Portanto, ao sintetizar essas influências, corre-se o risco de praticar injustiças e imprecisões, deixando de nomear colaboradores importantes.

Atualmente, psicanálise é uma prática clínica que se refere à análise de pacientes tratados individualmente e de uma metapsicologia que teoriza as particularidades desta prática clínica. A partir dos anos 1940, esse saber tem sido aplicado em outros contextos: grupos, famílias e casais. O surgimento dessas novas práticas é decorrente de problemas clínicos que a modalidade terapêutica tradicional não permitia abordar (Berenstein, 2003).

A idéia da intersubjetividade é absorvida de diferentes modos dentro da psicanálise: como relação objetal, como o discurso dirigido a um outro e como um espaço intersubjetivo entre um eu e um outro. Observamos aqui a influência das correntes kleiniana, lacaniana e winnicottiana, respectivamente. Podemos extrair desta afirmação a complexidade da questão histórica, isto é, os trabalhos vinculares estão no centro de um cruzamento de saberes. 
A psicanálise de grupos é transgressiva, principalmente no tocante ao setting tradicional, em que seu dispositivo face a face provoca a excitação do olhar. Por isso chama-se configuração vincular, abarcando nessa terminologia todos os trabalhos desenvolvidos com grupos, famílias, casais e instituições.

Especificamente ao campo dos grupos é inegável que a obra de Bion (1948/1975), "Experiências com grupos", forneceu o primeiro referencial para o enfoque analítico dos grupos.

Nessa obra, Bion elaborou um modelo teórico que permite articular duas modalidades de funcionamento psíquico em grupos pequenos. A primeira modalidade define o grupo de trabalho, no qual prevalece os processos da lógica secundária. A segunda define o grupo de pressupostos básicos e suas tensões com o grupo de trabalho. Os pressupostos básicos são constituídos por emoções intensas de origem primitiva, inconscientes e submetidas ao processo primário. São reações defensivas e regressivas impostas ao sujeito pelas angústias despertadas na situação de grupo. Os três pressupostos básicos são: dependência, acasalamento e luta e fuga, cada um corresponde a uma cultura de grupo.

Seguiram-se, então, algumas obras pilares, como "Psicoterapia del grupo" e "El grupo psicológico", dos autores argentinos Grinberg, Langer e Rodrigué. Obviamente, o desafio de então era desenvolver uma técnica que pretendia ser uma psicoterapia de grupo e não uma psicoterapia em grupo.

Conseqüentemente, precisavam superar um obstáculo ainda maior, isto é, não ser reconhecida como mera extensão da psicanálise aplicada.

Os grupos operativos de Enrique Pichón-Riviére contribuem com o desenvolvimento dessa modalidade de atendimento, embora tenham como 
especificidade o trabalho centrado em uma tarefa. Esse autor contribui significativamente para o desenvolvimento do conceito de vínculo.

O vínculo é um conceito que alude tanto ao mundo interno como ao mundo externo, situando-se entre as concepções intrapsíquica, intersubjetiva e transubjetiva. Observa-se aqui como as concepções de transferência e contratransferência estão apreendidas nesse conceito, na medida em que falamos de uma relação onde ocorre uma experiência emocional entre duas ou mais pessoas ou entre partes de uma mesma pessoa (Fernandes \& Fernandes, 2003).

Berenstein (2003), esclarece e aprofunda a importância da noção de vínculo e o motivo de seu esquecimento na literatura psicanalítica:

A partir da noção de vinculo podemos postular agora a multiplicidade do ego: ele está investido de sua especificidade como sujeito do vinculo e aparece como múltiplo, dado que ele se constitui através de sua pertença a uma relação. Duplo ataque narcísico à concepção cartesiana do eu: o eu não é inteiro, mas dividido, não é único, mas múltiplo e, além disso, é determinado em sua relação com o outro (Berenstein, 2003, p. 190, grifo do autor).

Seguiram-se nomes como Siegmund Foulkes e H. Ezriel, na Inglaterra, que deram origem à chamada corrente grupoanalítica, caracterizando-se como uma técnica e um dispositivo de experiência psicanalítica do inconsciente em situação de grupo. Os conceitos de grupo como matriz psíquica e ressonância fantasmática provêm dessa corrente.

Nos Estados Unidos podemos citar Samuel R. Slavson e Paul Schilder.

Didier Anzieu e René Kaës, na França, irão retomar a idéia do estatuto de objeto psíquico que o grupo tem para o sujeito singular. 
história, sua colocação na fantasia inconsciente, a idiossincrasia de suas pulsões, de suas representações, de seu recalcamento (Kaës, 1997, p. 68).

Em comum podemos destacar a teoria do laço ou do vínculo como pressuposto básico. Este é o conceito que dá sustentação teórica ao desenvolvimento da idéia do trabalho psíquico da intersubjetividade.

Nos últimos anos, articularam-se diversas construções teóricas de psicanalistas franceses e latino-americanos em torno da questão do grupo e das configurações vinculares. O grupo seria então o elo entre o sujeito da psicanálise tradicional, as instituições e a cultura (Correa, 2002). 
3.2 A contribuição de René Kaës

René Kaës é um autor que pretende manter uma fidelidade aos conceitos freudianos, a fim de explicitar mecanismos psíquicos no dispositivo grupal. Porém, também não se restringe ao âmbito dos grupos, detendo-se na compreensão da intersubjetividade no contexto analítico. Procura estabelecer um campo de pesquisa e prática cuja especificidade reside no estudo das correlações das organizações intrapsíquicas e das formações do vínculo intersubjetivo (Kaës, 1997).

A principal preocupação de Kaës se refere a construir uma metapsicologia grupal, a fim de que possa abordar o grupo como um objeto psicanalítico. Não tem uma preocupação com o social, no que diz respeito a uma sociologia, tampouco com uma ideologia. O seu trabalho visa à compreensão psicanalítica dos fenômenos grupais, por via da intersubjetividade e suas possíveis influências na realidade psíquica individual, ou seja, no intrapsíquico. Ocupa-se de construir um aparato teórico, que compreenda o trabalho psíquico intersubjetivo em relação ao intrapsíquico.

Todas essas especificidades do trabalho de René Kaës foram ao encontro das questões suscitadas pelo trabalho terapêutico com grupos. Por isso, justifica-se a escolha de nos determos especialmente às suas formulações.

Para compreender alguns conceitos temos que deixar explícita uma premissa básica desse autor, a saber: o grupo antecede e constitui o sujeito singular. Ao grupo, no caso o familiar, caberia a tarefa de instalar a alteridade no sujeito. 
Desse modo, o conceito de realidade psíquica não se aplicaria restritamente ao espaço individual constituído no apoio corporal, mas sim postular uma realidade psíquica nos grupos, disparada pelo encontro intersubjetivo.

Assim, cabem aqui algumas palavras sobre o conceito de apoio. No capítulo em que discorremos sobre a constituição do sujeito, abordamos o conceito de apoio através da formulação freudiana de que as pulsões sexuais se originam apoiadas na satisfação das pulsões de autoconservação. Kaës utiliza a expressão em francês etayage, traduzida em espanhol como apuntalamiento, que em português se aproximaria do verbete "ancoragem", para explicitar que o apoio modela e transforma o que sustenta. Assim, postula que o grupo, ao qual um sujeito pertence, também dará esta sustentação ao psiquismo.

El registro intrapsíquico, coincidente com el comienzo de un aparato psíquico que lo contiene, implica entonces un primer bosquejo de diferencia adentro-afuera. Todos estos surgimientos son simultáneos. En la estructura de esta primera fantasía encontraremos la marca de un doble apuntalamiento: en el cuerpo del niño (la sexualidad se apuntala sobre la autoconservación) y en el grupo (a través de su porta-voz, la madre) (Kaës (1984) apud Bernard, 2003).

Para articular o conceito de grupo à hipótese do inconsciente, Kaës (1997) propõe algumas designações para o conceito, a saber: a forma e a estrutura paradigmáticas de uma organização de vínculos intersubjetivos, sob o prisma de que as relações entre vários sujeitos do inconsciente produzem formações e processos psíquicos específicos; também designa uma organização intrapsíquica caracterizada por ligações mútuas entre seus elementos e pelas funções que desempenha no aparelho psíquico e, finalmente, nomeia um dispositivo de investigação e de tratamento das formações e dos processos de realidade psíquica envolvidos na reunião de sujeitos num grupo. 
Isto significa que para ele o sujeito intrapsíquico é constituído e apoiado na sua estrutura familiar, no corpo e na relação com o corpo do outro, ou seja, na condição de grupabilidade.

O grupo familiar é o grupo real de pertencimento primário, no qual uma criança se desenvolve. Esse grupo é, portanto, constitutivo e por essa razão chamado de grupo interno, que vem a ser a internalização dos personagens do grupo de pertencimento primário. O grupo primário contém as primeiras figuras de identificação. Assim, por via da transferência, esse grupo será deslocado para os grupos de pertencimento secundários. Conseqüentemente, podemos afirmar que qualquer processo psíquico individual ocorrerá dentro de algum tipo de pertencimento grupal, quer seja em uma clínica psicanalítica tradicional, quer seja em uma instituição.

A maior ou menor capacidade de distanciamento em relação ao grupo de pertencimento primário é o que possibilita o trabalho em pequenos grupos, pois se distanciar significa separar-se de certas introjeções e repetições na constituição do eu.

"Como Freud sublinhou em `Psicologia das massas e a análise do ego', o Eu, para pensar e se pensar, deve romper com o grupo que o precede (...) “ (Kaës, 1997, p. 25).

O processo de distanciamento não significa se individualizar, mas sim um processo anterior a este e que emerge da estrutura grupal. É através da intersubjetividade que esses sujeitos mais distanciados atuarão sobre a subjetividade dos outros nos grupos. Esse processo de distanciamento nada mais é senão a constituição subjetiva que se apóia na dinâmica do grupo de pertencimento 
primário, ou seja, tornar-se determinado pelos laços constitutivos, porém autônomo dos mesmos.

Outro conceito fundamental é o de realidade psíquica:

"As pesquisas psicanalíticas feitas sobre grupos, depois de Freud, se organizam sob a hipótese de que o grupo, enquanto conjunto intersubjetivo, é o lugar de uma realidade psíquica própria" (Kaës, 1997, p. 61).

Assim, os conceitos de realidade psíquica e trabalho psíquico são fundamentais. Entendendo por trabalho psíquico um gasto de energia intrapsíquico e intersubjetivo, na medida em que envolve um vínculo e se desencadeia através do outro. A energia psíquica é sempre intrapsíquica, mas depende dos vínculos ou laços intersubjetivos; privilegia-se, portanto, as relações objetais. O trabalho psíquico na intersubjetividade conduz a uma ruptura e, conseqüentemente, a uma transformação e a um trabalho de criação.

Assim, para esse autor, o trabalho psíquico da intersubjetividade diz respeito às condições nas quais o sujeito do inconsciente se constitui:

Admite como hipótese fundamental que cada sujeito na sua singularidade adquire em diversos graus a aptidão de significar e interpretar, de receber, conter ou rejeitar, ligar e desligar, transformar e representar (-se), de representar com - ou destruir - objetos e representações, emoções e pensamentos que pertencem a outro sujeito, que transitam através de seu próprio aparelho psíquico ou vem a tornar-se, por incorporação ou introjeção, partes enquistadas ou integrantes e reutilizáveis. Essa noção admite como conseqüência do conceito do sujeito do grupo a idéia de que cada sujeito é representado e procura fazer-se representar nas relações de objeto, nas imagos, nas identificações e nas fantasias inconscientes de um outro e de um conjunto de outros: assim também, cada sujeito liga entre eles e se liga numa das formações psíquicas desse tipo com os representantes de outros sujeitos, com os objetos que hospeda dentro de si (Kaës, 1997, p. 283).

Esse trabalho psíquico se daria por via de renúncia, na medida em que um sujeito só se liga a outro caso tenham em comum aspectos excluídos, para que 
se possa dar o laço. Assim, Kaës alerta para um componente fundamental do conceito de identificação, ou seja, existe "algo a mais" para que as pessoas se unam. Esse "algo a mais" seria a renúncia comum compartilhada, que nos remete ao mecanismo de recalque ou às figuras do negativo em psicanálise.

Citando diretamente Freud (1921/1987I), para esclarecer a questão do conteúdo recalcado como condição inerente às identificações:

\begin{abstract}
Suponha-se, por exemplo, que uma das moças de um internato receba de alguém de quem está secretamente enamorada uma carta que Ihe desperta ciúmes e que a ela reaja por uma crise de histeria. Então, algumas de suas amigas que são conhecedoras do assunto pegarão a crise, por assim dizer, através de uma infecção mental. O mecanismo é o da identificação baseada na possibilidade ou desejo de colocar-se na mesma situação. As outras moças também gostariam de ter um caso amoroso secreto e, sob a influência do sentimento de culpa, aceitam também o sofrimento envolvido nele. Seria errado supor que assumissem o sintoma por simpatia. Pelo contrário, a simpatia só surge da identificação e isso é provado pelo fato de que uma infecção ou imitação desse tipo acontece em circunstâncias em que é de presumir uma simpatia preexistente ainda menor do que a que costumeiramente existe entre amigas, numa escola para moças. Um determinado ego percebeu uma analogia significante com outro sobre certo ponto, em nosso exemplo sobre a receptividade a uma emoção semelhante. Uma identificação é logo após construída sobre esse ponto e, sob a influência da situação patogênica, deslocada para o sintoma que o primeiro ego produziu. $A$ identificação por meio do sintoma tornou-se assim o sinal de um ponto de coincidência entre os dois egos, sinal que tem de ser mantido reprimido (Freud, 1921/1987I, pp. 135-136, grifo nosso).
\end{abstract}

Concluindo, o laço ou vínculo se constitui muito mais por meio da negatividade do que pela positividade aparente da identificação, na medida em que esta não se dá pelo que é singular no sujeito, mas sim por áreas negadas em comum com o objeto com o qual se identifica.

De modo geral, esse é o panorama das contribuições de René Kaës, no qual faremos um recorte, com o intuito de compreender e lançar luz ao conceito de intersubjetividade.

Para tanto, ainda nos deteremos nas especificidades de alguns dos conceitos que aqui apenas nomeamos. 
3.3 Alguns conceitos fundamentais: o negativo e o intermediário

Para que haja compreensão de um conceito fundamental na obra de René Kaës, o pacto denegativo, é necessário retomarmos uma reflexão sobre a figura do negativo na psicanálise.

Conforme propõe Kaës (2003b), em Freud podemos observar sentidos bastante diversos para a palavra negativo: o de uma inversão, quando opõe a neurose à perversão ou quando qualifica uma forma de alucinação (a alucinação negativa), o de uma qualidade agressiva da transferência (a transferência negativa) e o de certas reações de rejeição do processo terapêutico (a reação terapêutica negativa). Essa análise evidencia a utilização da expressão negativo como uma qualificação, ou seja, adjetivando um tipo de reação ou mecanismo.

Kaës (2003b) ressalta que a reflexão sobre o negativo como uma categoria substantiva acentua três conotações principais: a ausência de representação ou de representabilidade, um destino nocivo do funcionamento psíquico e a experiência da ausência ou da falha. Segundo o mesmo autor, sobre essa negatividade apóia-se a positividade que estrutura a vida psíquica.

Podemos retomar aqui a análise que Freud propõe em Sobre o Narcisismo: ele mostra de que modo o narcisismo de Sua Majestade, o bebê, apóia-se, afasta-se ao mesmo tempo que encontra um modelo sobre o narcisismo dos pais. Por um lado, esse narcisismo é marcado pelo negativo, isto é, pelos "sonhos de desejos irrealizados" dos pais. A criança é investida narcisicamente como o prolongamento e a realização do narcisismo dos pais, ali onde seus narcisismos foram entravados, deixados insatisfeitos. Esse texto é um ponto de partida para compreender de que modo funciona o negativo na transmissão da vida psíquica (Kaës 1998, apud Rouchy \& Desroche, 2005, p. 22, grifo do autor). 
$\mathrm{Na}$ atualidade da clínica, a figura do negativo se manifesta como

sintoma na experiência do vazio e da angústia de aniquilação. Metapsicologicamente, refere-se à ausência de inscrição no universo das representações, e na visão processual está ligada a uma atividade de desligamento para impedir a destruição da função de ligação ao objeto (Fernandes, 2003a).

Estos dispositivos [de grupo] nos permitieron pensar con nuevos conceptos lo que se transfiere y se transmite del espacio psíquico de un sujeito al espacio psíquico de otro sujeito, o de más de un sujeito, y en el espacio intersubjetivo que se construye a partir de sus vínculos. Lo que se transmite son esencialmente configuraciones de objetos psíquicos, es decir objetos equipados con vínculos a los que cada sujeito precede. Lo que se transmite y constituye la prehistoria del sujeito, no es solamente lo que sustiene y asegura, en positivo, las continuidades narcisisticas y objetales, el mantenimiento de los vínculos intersubjetivos, las formas y los procesos de conservación y de complejización de la vida: ideales, mecanismos de defensas neuróticos, identificaciones, pensamientos de certeza. Un carácter notable de estas configuraciones de objetos de transmisión es que están marcados por lo negativo. Lo que se transmite es lo que no pudo ser contenido, lo que no se retiene, no se recuerda, no encuentra inscripción en la psiquis de los padres y viene a depositarse o enquistarse en la psiquis de un niño: la falta, la enfermidad, el crimen, los objetos desaparecidos sin huella ni memoria, para los que no pudo realizarse un trabajo de duelo (Kaës, 2004, p. 669).

Define três modalidades do negativo observáveis na prática clínica, a

saber:

a) a negatividade de obrigação, que corresponde à necessidade do aparelho psíquico de produzir o negativo com o objetivo de efetuar o trabalho de ligação,

b) a negatividade relativa, que situaria o negativo em relação a um possível e,

c) a negatividade radical, ou seja, a categoria do impossível ou daquilo que não está no espaço psíquico. 
A idéia de negatividade radical implica o ataque a qualquer vínculo que faça algum tipo de elo. Na clínica se manifesta de dois modos diferentes, mas que geram o mesmo resultado: adesão total uns aos outros ou ataque à ligação entre as pessoas.

Partindo do estudo sobre o negativo, Kaës postula o que chama de pacto denegativo, ou seja, só há recalque individual no que negamos conjuntamente no grupo. Desse modo, o pacto denegativo se apresenta como organizador do vínculo e do conjunto, mas também como uma polaridade defensiva dos aspectos recalcados. Essa idéia coloca em ação mudanças psíquicas intersubjetivas e intrapsíquicas rapidamente, conforme a configuração do grupo e do emergente.

Por pacto denegativo compreendo aquilo que, em todo conjunto transubjetivo é voltado de comum e inconsciente acordo ao destino do recalque ou da denegação, da negação, do desmentido, da rejeição, do enquistamento: para que o laço se organize e se mantenha (...) para satisfazer a dupla economia cruzada dos sujeitos singulares e da cadeia de que eles são membros (...) cada conjunto se organiza positivamente sobre investimentos mútuos, sobre identificações comuns, sobre um contrato narcísico (...) e negativamente sobre uma comunhão de renuncias e de sacrifícios, sobre apagamentos, rejeições e recalques (...) Nos casais, nas famílias, nos grupos e nas instituições, as alianças, contratos e pactos inconscientes sustentam aí principalmente o destino do recalque e da repetição (Kaës, 2005, pp. 132-133, grifo do autor).

O intermediário é uma categoria que oferece uma abertura entre os espaços intrapsíquico e intersubjetivo, na medida em que se constitui como um conceito mediador entre duas ordens heterogêneas de realidade. Assim, permite articular os espaços intrapsíquico e intersubjetivo.

Kaës (2003b) mostra como a concepção de intermediário atravessa as idéias de Freud da primeira a segunda tópicas. A mãe, por exemplo, desenvolve uma função de intermediária entre o bebê e o mundo externo, o pré-consciente como um espaço entre inconsciente e consciente, as formações de compromisso (sintoma, sonhos, atos falhos, chistes) entre o desejo e a defesa, o ego como 
mediador entre as exigências do id, do superego e da realidade. Desse modo, as formações intermediárias podem nos remeter, conseqüentemente, ao que está recalcado.

Observa-se que Freud recorre a noção de intermediário quando está confrontado a pensar duas ordens: dentro / fora, consciente / inconsciente, realidade externa / aparelho psíquico.

Na segunda tópica freudiana, a categoria do intermediário sofrerá algumas mudanças, pois se aplicará também ao objeto. Em "Além do princípio de prazer" (Freud, 1920/1987k), a utilização de um objeto e da linguagem em um jogo (o jogo do carretel: Fort! Da!) manifesta a função intermediária do carretel e da linguagem para articular o controle da ausência do objeto (Kaës, 2005). Tanto o objeto-carretel quanto a linguagem ocupam uma posição e desenvolvem uma função intermediária, isto é, auxiliam na elaboração e no manejo da angústia gerada pela ausência do objeto-mãe.

Tal como Freud (1895/1987a) compreendia o traumatismo, ou seja, o resultado das excitações fortes o suficiente para superarem a barreira de proteção, aqui podemos compreender o trauma como o resultado de um fracasso nas formações intermediárias.

Observam-se duas ordens distintas de formações intermediárias: as intrapsíquicas (sintomas, sonhos e formação do ego) e as interpsíquicas (mediador, representante, objeto substituto e porta-voz).

Kaës $(1994,2005)$ atenta para o fato de, nos textos pertencentes à primeira tópica freudiana, a noção de intermediário identificar-se com a instância do pré-consciente, na medida em que nesta instância se realiza a maior parte das transformações que constituem a passagem das representações inconscientes para 
a consciência. Já na segunda tópica, o pensamento freudiano tratará da articulação deste conteúdo interno com o externo e, conseqüentemente, a função do intermediário se identificará com a instância do ego.

É importante ressaltar que as formações intermediárias descritas acima são provenientes de uma leitura metapsicológica e desempenham uma função psíquica vital, a saber: executam a ligação, possibilitando relações simbólicas e toleráveis para o psiquismo e exercendo uma função de prótese e de mediação, na medida em que permite articular diferentes elementos, por vezes antagônicos e conflitantes.

Outro conceito relevante e complementar à noção de intermediário refere-se à aliança inconsciente, uma formação psíquica intersubjetiva construída pelos sujeitos de um vínculo para reforçar, em cada um deles, certos processos, certas funções, ou certas estruturas.

Para se associar em grupo (...) os humanos não somente identificam-se com um objeto em comum e daí, igualmente entre eles, selando também um acordo inconsciente segundo o qual, não se dará atenção a um certo número de coisas: elas devem ser recalcadas, rejeitadas, abolidas, depositadas ou apagadas. Mas ao manter um ar de simulacro, elas abrem também um espaço onde o possível pode ser inventado (Kaës, 1997, p. 257). 
3.4 Novos dilemas técnicos ou velhos conhecidos reeditados?

Cabe aqui uma explicitação do que vem a ser a psicanálise em extensão e a psicanálise em intenção. A primeira diz respeito a todas as presencialidades da psicanálise não intimamente ligadas à situação do tratamento psicanalítico, a chamada psicanálise aplicada; a segunda refere-se à singularidade da experiência clínica psicanalítica. Importa lembrar que a chamada psicanálise aplicada refere-se à aplicação de conceitos psicanalíticos na análise de objetos inanimados, que não associam livremente, não estabelecem relações transferenciais e nem se modificam mediante interpretações.

No tratamento de grupos, o setting psicanalítico deixa de ser respeitado em vários aspectos, entre eles por ser um grupo de pessoas e pela ausência do divã que faz com que o olhar esteja em jogo na cena. Porém, Freud caracterizou o método psicanalítico não só pela utilização do divã mas, principalmente, pela associação livre por parte do paciente e pela atenção flutuante por parte do analista.

O grupo como dispositivo analítico é o lugar do laço e da transferência onde aquilo que se diz pode adquirir um outro sentido e pode ser interpretado. Pode ser compreendido como um espaço transicional que tem como função ser continente às excitações.

Nos grupos não é apenas a palavra que está em jogo, mas também o corpo, isso nos remete a estruturações psíquicas mais primitivas. Isso quer dizer que, atualmente, os grupos são pensados como dispositivos para se trabalhar 
inscrições psíquicas que não foram estruturadas no campo simbólico e no campo da linguagem. Assim, é possível se capturar cenas por meio do olhar que não seriam perceptíveis no dispositivo tradicional e sequer estavam registradas no campo intrapsíquico do sujeito; sendo necessário um trabalho de semiotização primária, ou seja, de construção de sentido.

O olhar adquire um estatuto metapsicológico, pois ele marca sem sombras de dúvidas o afastamento intersubjetivo e a alteridade dos objetos. O que está colocado em pauta não é a ausência ou a falta do analista, mas sim sua presença e sua inegável alteridade.

Estelle: Sinto uma coisa esquisita. (Apalpa-se). Com você não é assim também? Quando não me vejo, por mais que me apalpe, fico na dúvida se existo de verdade.

Inês: Quer que lhe sirva de espelho? (...) Olhe nos meus olhos, está se vendo neles?

Estelle: Estou tão pequenininha. Vejo-me muito mal. (...) Hum! Está bem mesmo? Como é desagradável não poder julgar-me por mim mesma.

Inês: Eu sou o espelho das cotovias, minha pequena cotovia; pilhei-a! Não há vermelhidão alguma! (...) Que tal se o espelho começasse a mentir? Ou se eu fechasse os olhos, se não quisesse olhar, que faria você de toda essa beleza? (Sartre, 2005, pp.45-49).

O trabalho psíquico da intersubjetividade pressupõe pessoas com compreensão intrasubjetiva diferentes sobre um mesmo tema e também as obrigam a caminhar por essas diferenças. Assim, podemos dizer que um grupo opera através de superação de oposições.

A associação livre é substituída pela interdiscursividade, ou seja, a fala de cada sujeito constrói um discurso do grupo que será escutado com a atenção flutuante do analista. A fala no grupo implica um sujeito que fala e um sujeito que escuta; essa fala é tomada como a dramatização de cenas intrapsíquicas dentro de 
um cenário intersubjetivo. A atenção do analista deverá ser focada nas formações nodais, intermediárias e sintomáticas partilhadas pelos sujeitos. Assim, a fala de um sujeito será reconhecida como portadora de um valor psíquico por outro sujeito, que poderá reconhecer nela significantes que ele não tem disponível em si mesmo. Desse modo, a escuta do sujeito e a escuta do analista não se constituem apenas como uma escuta do outro e nem somente pela escuta de si mesmo, mas, principalmente, uma escuta do efeito da associação do outro. Supõe a pluralidade e a diversidade e, acima de tudo, o reconhecimento de diferentes linguagens, implicando abrir mão da idéia de unidade.

Por meio da intersubjetividade o grupo se torna um dispositivo clínico que possibilita e autoriza utilizar os conceitos metapsicológicos freudianos fora de seu estado nascente. Estado esse que se traduz como o sujeito singular tratado pelo dispositivo tradicional de cura.

A exigência metodológica da psicanálise é construir um dispositivo capaz de manifestar o inconsciente e seus efeitos de subjetividade. É possível construir tal dispositivo em uma instituição e, mais especificamente, em grupo? Na procura de resposta, encontramo-nos com Racamier (1970) apud Kaës et al. (1991), lembrando que o psicanalista não inventou seu campo de ação nas instituições. O campo é preexistente e o psicanalista deve conhecê-lo para poder atuar de acordo com as modalidades inteiramente psicanalíticas numa situação ainda inexistente no âmbito do trabalho clínico.

Gostaríamos também de explicitar que o grupo aqui é compreendido como um dispositivo utilizado para a captura de aspectos inconscientes e não como um objeto de estudo propriamente dito. Tal diferenciação implica diferentes manejos técnicos e teóricos dos grupos terapêuticos. Assim, compreendemos que as 
manifestações inconscientes produzidas nos grupos são de ordem do sujeito singular, intrapsíquico e desencadeadas pelas relações intersubjetivas e pela associação livre produzida no dispositivo grupal.

Está claro que, ao pensar a prática psicanalítica dentro de um setting diferente do proposto pela cura tradicional, faz-se necessário uma nova representação da teoria e, conseqüentemente, a investigação de outros problemas epistemológicos.

O sujeito da psicanálise precisa de um outro para decifrá-lo por meio da interpretação - instrumento intersubjetivo, tendo como objetivo o desvelamento do inconsciente, o objeto de estudo.

As situações de grupos têm características que lhes são próprias e que determinam algumas mudanças no setting: pluralidade, face a face e interdiscursividade.

O grupo reúne vários sujeitos em um encontro múltiplo e intenso com vários objetos pulsionais, gerando um excesso de excitação. Mecanismos de identificação como forma de defesa são acionados, a fim de se produzir espaços psíquicos onde o laço é possível, através do recalque das representações perigosas.

O dispositivo face a face mobiliza a comunicação não verbal e os efeitos do olhar, mas a relação permanece no registro da palavra, uma vez que a regra fundamental e a interpretação da transferência continuam sendo as ferramentas de trabalho.

Em relação à interdiscursividade, os enunciados de palavra são inseridos em uma pluralidade de discursos, mas ordenados em uma cadeia associativa (Kaës, 2005). 
Freud (1912/1987d) descreve em seus artigos sobre a técnica uma série de recomendações e considerações sobre o setting e o início do tratamento psicanalítico. Assim, na cura tradicional, o setting definir-se-á pelo dispositivo divã / poltrona e pelo rigor quanto à regularidade e duração das sessões. Mas, o mobiliário não estaria tomando o lugar de destaque em detrimento da associação livre e da atenção flutuante? Conforme alerta Quinet (2000), divã é um termo persa que designa efetivamente um lugar de fala. O inconsciente e suas manifestações não se localizam estritamente dentro de um consultório corretamente mobiliado, mas sim onde existe um sujeito que fala e um outro com uma escuta específica.

El lugar del psicoanalista en el grupo es evidentemente un lugar fantasmático constituido, en la transferência, por la demanda de sujeitos singulares como tales, o por la de un sujeito constituido como porta-voz de la demanda de un conjunto intersubjetivo grupal (Kaës, 1994, p. 30).

Este tópico polemiza a questão da técnica psicanalítica, mas não tem a pretensão de menosprezar o enquadre tradicional em prol do dispositivo grupal, nem tão pouco qualificar o trabalho intersubjetivo como mais imprescindível que o trabalho intrapsíquico.

Para finalizar, faço minha as palavras de André Green apud Gibeault (2003):

A causalidade psíquica não pode mais se satisfazer de uma teoria das pulsões dentro de um solipsismo inaceitável, da mesma maneira que ela não encontra soluções satisfatórias numa teoria das relações de objeto que pretende deixar de lado a fonte dinâmica pulsional como motor do investimento e do desenvolvimento. Esta causalidade não é nem intersubjetiva, nem intrapsíquica, ela nasce da articulação da relação entre os dois (Green, 1998 apud Gibeault, 2003, p. 82). 


\section{DELIMITAÇÃO DO MÉTODO}

4.1 Pesquisa em psicanálise

O referencial teórico, em que está fundamentada a pesquisa bibliográfica, é proveniente da Psicanálise, que delimita o campo subjetivo e tem como objeto de estudo o Inconsciente.

Na clínica é caracterizada pela associação livre, por parte do paciente, e na interpretação dos conteúdos inconscientes, por parte do analista. Os fragmentos clínicos contidos neste trabalho têm por objetivo ilustrar a pesquisa teórica. Logo, não temos intenção de fazer um estudo quantitativo dos dados obtidos nos grupos terapêuticos, mas sim um estudo qualitativo.

O corpo teórico da Psicanálise se caracteriza por ser um método de investigação, ao mesmo tempo em que implica uma prática clínica. Desse modo, não há como teorizar sobre Psicanálise sem sua vertente prática, pois o método de investigação coincide com o método de tratamento. A investigação do inconsciente se dá através da transferência, que caracteriza o método psicanalítico, ou seja, a singularidade da experiência clínica psicanalítica.

Conforme ressalta Safra (1993), quando se faz pesquisa tendo como modelo a psicanálise, há a necessidade de se integrar à teoria o material clínico 
obtido, mediante as entrevistas realizadas com o paciente, com o intuito de garantir o rigor metodológico.

Desse modo, uma descrição clínica é sempre uma reconstrução a partir da memória do analista. Além disso, a experiência clínica apresenta uma infinidade de fenômenos possíveis de serem alcançados por um único vértice ou concepção teórica (Safra, 1993).

Considerando-se os fenômenos transferênciais característicos da clínica psicanalítica, observamos que o fragmento clínico é sempre uma verdade intersubjetiva em uma versão recortada a partir da memória do analista, gerando uma produção de conhecimento. Com isto visamos explicitar a subjetividade presente na pesquisa psicanalítica.

Segundo Mezan (1993, p. 57):

Por ser atividade a dois, e não apenas reflexão individual, a psicanálise quer mais do que elucidar o objeto de que se ocupa: quer também transformá-lo ou pelo menos propiciar as condições para que ele possa se autotransformar com o auxílio do outro, o psicanalista.

Nessa incursão teórica e prática, o referencial psicanalítico é utilizado nas diversas vertentes possíveis:

- como método de investigação;

- como teoria para a compreensão das questões levantadas nos grupos;

- como forma de tratamento.

Em seu texto "Sobre o ensino da psicanálise nas universidades", Freud (1919/1987j) deixa claro que o ambiente da universidade é pensado como um canal 
de divulgação da psicanálise e não como um lugar adequado para a investigação. Esta última só poderia se dar no âmbito de uma prática clínica que, na época, coincidia com o consultório privado. Porém, com a multiplicidade de tendências na psicanálise contemporânea, esse panorama mudou e novas concepções tiveram que ser abarcadas.

Reiteramos que existe na psicanálise uma indissociável relação entre a investigação e o tratamento, portanto a pesquisa em psicanálise se configura na produção de saber dentro da própria relação terapêutica.

"A clínica psicanalítica opera a partir do que se apresenta da realidade psíquica nos desdobramentos da fala, da produção discursiva, de um sujeito que se endereça a alguém através da transferência" (Figueiredo, 2001).

Não obstante, também podemos nos sustentar em uma metapsicologia, uma psicopatologia e uma teoria do processo terapêutico presentes no escopo teórico psicanalítico.

Uma vez definida a pesquisa, podemos aplicar as contribuições do método clínico à pesquisa qualitativa, na medida em que esse método pode ser aplicado aos grupos como uma investigação ativa diante da observação embasada por um referencial teórico, no caso, a Psicanálise.

... o método clínico, se caracteriza por uma observação detalhada, cuidadosa e completa, realizada em um enquadramento rigoroso; este enquadramento podese definir como o conjunto das condições nas quais se realiza a observação e constitui uma fixação de variáveis ... (Bleger, 1984, p. 46).

A pesquisa qualitativa pressupõe um método compreensivo ou interpretativo. Para tanto, os seus sustentadores são a realidade fenomenológica, a prática clínica e o referencial teórico. Assim, temos por objetivo estudar e rever 
pressupostos, a fim de aprofundar conclusões e não estudar fenômenos com o intuito de generalizar.

Este trabalho foi submetido ao Comitê de Ética em Pesquisa do Hospital do Servidor Público Estadual; bem como o Termo de Consentimento Livre e Esclarecido, tendo sido aprovado, registrado e arquivado sob o $\mathrm{n}^{\circ}$ 050/05. 
4.2 Contextualização da instituição de saúde

O Instituto de Assistência Médica ao Servidor Público Estadual (IAMSPE) se constitui como uma autarquia, isto é, entidade autônoma descentralizada da administração pública, porém sujeita à fiscalização do Estado. Tem por objetivo a prestação de serviços de caráter estatal ou de interesse da coletividade. É uma instituição que atende aos funcionários públicos do Estado de São Paulo e aos seus dependentes, caracterizando-se como Hospital-Escola, em virtude de seu incentivo ao ensino e à pesquisa.

O Serviço de Psiquiatria e Psicologia Médica foi criado em 1964 e, atualmente, fazem parte de seu organograma a enfermaria, o hospital-dia e o ambulatório. Desde sua criação, esse Serviço diferenciava-se do modelo de assistência psiquiátrica tradicional, haja vista a Unidade Psiquiátrica dentro de um Hospital Geral, com o ambulatório e a enfermaria. A enfermaria é usada somente quando a internação é indispensável, pois se valoriza a tendência de tratar o paciente o mais próximo possível de seu ambiente de origem. Segundo Sonenreich e Estevão (1996), essa proposta de Unidade Psiquiátrica em Hospital Geral é uma das pioneiras no campo da saúde mental no Brasil.

Ainda na década de 1960, ocorreu a instalação de serviços de terapia de grupo de orientação analítica em duas importantes clínicas psiquiátricas em São Paulo: a da Faculdade de Medicina da Universidade de São Paulo e a do Hospital do Servidor Público Estadual (Fernandes, Svartman \& Fernandes et al., 2003). 
A Seção de Psicologia iniciou suas atividades no Hospital através de tarefas que mesclavam atividades clínicas e organizacionais, discriminando e delineando sua identidade clínica e hospitalar no início dos anos 1970. Com o passar do tempo, cada vez mais os trabalhos nas diferentes clínicas e no ambulatório da psicologia foram se ampliando, e, em outubro de 2003, a Seção de Psicologia adquiriu a autonomia administrativa, tornando-se uma seção independente do Serviço de Psiquiatria.

Desde então, a Seção de Psicologia em sua estrutura organizacional possui uma Chefia que responde a uma Diretoria Clínica da Divisão de Clínicas Gerais do complexo hospitalar.

Todos os encaminhamentos para a Seção de Psicologia, anteriormente realizados somente pelo Serviço de Psiquiatria e Neurologia, agora podem ser feitos por qualquer clínica do Hospital, inclusive por procura espontânea dos pacientes.

Atualmente, a prioridade da instituição é o desenvolvimento de trabalhos em equipes multiprofissionais e interdisciplinares. Assim, o trabalho do psicólogo na Seção de Psicologia se desenvolve em duas grandes vertentes, a saber:

a) os trabalhos de interconsulta e inserção em Equipes Multiprofissionais no Hospital Geral; e

b) os trabalhos clínicos no Ambulatório da Psicologia.

Os psicólogos da Seção de Psicologia dividem-se em três faixas etárias para o atendimento. São elas: infantil, adolescente e adulto. Realizam atendimentos em triagem, psicodiagnóstico e psicoterapias, individuais ou em grupo. 
Atualmente a equipe se constitui por 15 psicólogos concursados, 01 comissionado e 08 aprimorandos em Psicologia Clínica e Psicologia Hospitalar, com vínculo empregatício pela Fundação para o Desenvolvimento Administrativo (FUNDAP). O referido aprimoramento faz parte do Programa de Aprimoramento Profissional (PAP) da FUNDAP, desenvolvido no Instituto de Saúde com o projeto de Aprimoramento em Saúde Coletiva, e suas atividades foram iniciadas em 1984.

O primeiro contato que mantive com a instituição data de 1990, quando realizei o Aprimoramento em Psicologia Clínica. No período de um ano que lá permaneci, tive a oportunidade de ter o primeiro contato com o atendimento de grupo, especificamente um "Grupo de Orientação a Pais".

Em 1994 ingressei na instituição e desenvolvi atividades direcionadas para a área de adultos, em que a prioridade era atender a demanda de trabalho no ambulatório da Psicologia. Desde então, tenho somado muitas experiências com o atendimento a diversos grupos terapêuticos em ambulatório, semente da origem do meu interesse nesse campo de conhecimento.

Em 1998 comecei a desenvolver atividades ligadas ao Programa de Aprimoramento Profissional (PAP), na preceptoria e supervisão do Aprimoramento em Psicologia Clínica e Hospitalar.

Como pode se observar, uma das características dessa instituição é a importância dada à formação e capacitação de seus profissionais, estimulando a pesquisa e a formação acadêmica continuada.

Em relação aos procedimentos de rotina de serviço, estabelecem-se algumas diferenças relativas ao setting característico do Hospital ou Ambulatório: os trabalhos de Interconsulta e inserção em Equipes Multiprofissionais são realizados nas diversas Clínicas Especializadas do complexo hospitalar. Os pedidos de 
intervenção são encaminhados diretamente à Seção de Psicologia e atendidos prontamente, na medida em que têm um caráter de urgência, por razão de envolver pacientes internados. No entanto, não nos deteremos nessa vertente do trabalho no Hospital, por não se constituir o campo específico desta proposta, embora também se realizem grupos nesse contexto, ou seja, fora do Ambulatório da Psicologia.

No Ambulatório, os pacientes chegam, muitas vezes, advindos das inúmeras Clínicas Especializadas do Hospital do Servidor ou por meio de procura espontânea. Nos encaminhamentos realizados pelas clínicas pode existir a solicitação prévia por determinado tipo de atendimento, quer seja psicodiagnóstico, quer seja psicoterapia. Porém, independentemente dessa solicitação, o profissional pode dar o direcionamento que, a seu ver, é o mais adequado ao caso. Assim, nem sempre a indicação de psicoterapia é a mais conveniente. Em havendo esse pedido de atendimento, o paciente é instruído como proceder, por conseguinte não há como esgotar totalmente a demanda institucional, por mais que a Seção de Psicologia possa contar com um grande número de profissionais.

Os pacientes chegam semanalmente para a triagem da Psicologia. A triagem tem como objetivo ser a porta de entrada de pacientes e o primeiro momento de avaliação da demanda do paciente. Assim, as condutas necessárias são provenientes desse contato; além disso, esse contato pode ter um caráter interventivo, na medida em que a demanda de realizar psicoterapia pode ser um desejo apenas do terapeuta. Eventualmente, quando há dúvidas sobre o melhor encaminhamento do paciente, dentro ou fora da Psicologia, a triagem pode ser estendida para um número maior de atendimentos, a critério do psicólogo responsável. Quando necessário, o paciente também pode ser encaminhado para os 
outros serviços especializados, tais como: terapia ocupacional, fonoaudiologia, assistência social ou qualquer outra especialidade médica.

Fazem parte dos procedimentos da Seção de Psicologia alguns encaminhamentos com critérios estabelecidos, são eles: psicodiagnóstico, psicoterapia breve, grupo de pais e psicoterapia de grupo. Neste trabalho, o foco abordado compreende os critérios de encaminhamento à fila de espera para Psicoterapia de Grupo no Ambulatório.

Os grupos são constituídos por pacientes que aguardam em uma fila de espera que, eventualmente, é fechada para novas inscrições, a fim de que o tempo entre a inscrição e a convocação para o início do tratamento não seja muito amplo. A seleção de pacientes é baseada no diagnóstico clínico, que caracteriza os critérios de grupabilidade, pretendendo-se uma homogeneidade em relação à estrutura de personalidade e não em relação à sintomatologia apresentada. Concordamos com as idéias de Zimmermann (1971), que salienta o cuidado na seleção de pacientes para grupo, evitando-se depressões severas, caráter oral agressivo e grandes diferenças de faixa etária, nível social, cultural e intelectual.

Após a triagem, o paciente aguarda em fila de espera para o atendimento psicoterápico grupal. Antes de se inserir no grupo, o paciente é convocado para uma, ou quantas forem necessárias, entrevista individual com o terapeuta do grupo. Durante esse intervalo, promove-se a circulação de informações básicas para o início do trabalho, momento em que se constrói o campo terapêutico e se situa a demanda, de modo a abordar e tratar todas as "dores" que são trazidas como queixa manifesta. Também é o momento de retificação dos critérios de grupabilidade, uma vez que são vários os profissionais que realizam a triagem e, por mais homogêneo que possa ser o raciocínio clínico de uma equipe, sempre lidamos 
com diferenças significativas e saudáveis. No entanto, essas diferenças não devem interferir na prática clínica, bem como não devemos deixar de considerar o tempo que se passa entre a triagem e a convocação, hiato no qual muitas mudanças podem ocorrer.

Para se desenvolver a proposta deste trabalho, foi utilizado o material clínico de dois tipos de grupos psicoterápicos conduzidos no ambulatório:

a) grupo aberto: as vagas são fixas e preenchidas de acordo com a saída espontânea ou com o abandono dos membros; e

b) grupo fechado: as vagas provenientes de abandono não são preenchidas, pois o grupo tem prazo preestabelecido para terminar.

Esses enquadramentos diferenciados de grupos propõem aos membros participantes determinados mecanismos de funcionamento, haja vista a finitude do vínculo previamente configurada no grupo fechado. 


\subsection{A instituição como objeto intra e intersubjetivo}

O conceito de objeto dentro do referencial psicanalítico já foi abordado no capítulo 2.2 "Considerações sobre o conceito de objeto em Psicanálise" deste trabalho, mas antes de tecer considerações sobre a instituição tendo um estatuto de objeto, faz-se necessário discorrer sobre o quê estamos nos referindo quando falamos em instituição.

Kaës (1991) propõe uma definição de instituição com a qual iremos nos articular neste tópico, a saber: a instituição é uma formação da sociedade e da cultura, sendo assim se opõe àquilo que é estabelecido pela natureza; é o conjunto das normas e das estruturas sociais instituídas pela lei e pelo costume; regula as nossas relações, preexiste e se impõe a nós. As instituições são dotadas de uma finalidade que a identifica e a distingue.

Conforme esse mesmo autor, as instituições são como uma ordem por onde se funda um coletivo com o objetivo de realizar uma tarefa útil, necessária para o funcionamento social, baseada em representações compartilhadas. A instituição é uma organização complexa onde intervém entre si diversas ordens de realidade: socioeconômica, jurídica, política, cultural e psíquica. Além da realidade psíquica que se forma na instituição, há as funções psíquicas caracterizadas pela satisfação dos desejos inconscientes, identificações, aspectos narcísicos, ideais, etc. (Kaës, 1991)

A tarefa primária da instituição é aquela que assegura a identidade da instituição e uma parte da identidade de seus membros. Existimos e mantemos laços 
com a instituição e com os outros na instituição, conforme definidos na relação com a tarefa primária da instituição. O prazer advém do cumprimento da tarefa primária sustentada por fantasias inconscientes e, conseqüentemente, o sofrimento psíquico nas instituições é proveniente do não cumprimento da tarefa primária ou do não reconhecimento da capacidade de seus membros.

Podemos concluir que a tarefa primária de uma instituição hospitalar pode ser definida como cuidar e/ou curar pessoas. Porém, a realidade psíquica no campo institucional não é homogênea, ou melhor, não se articula da mesma forma em nível do sujeito singular. Além disso, os movimentos antagônicos de forças presentes nos conflitos fundamentais criam, nas instituições de cuidados, não só o desejo e o poder de cuidar e reparar, mas também convocam o desejo e o poder de destruir (Kaës, 2004).

Nos conjuntos institucionais observamos formações que constituem os espaços psíquicos comuns e compartilhados. São espaços onde podemos encontrar as alianças inconscientes, as defesas comuns e os pactos denegativos (Kaës, 2004). Tal como definido anteriormente, os laços institucionais se dão do mesmo modo que os grupais, ou seja, por meio da negatividade.

De todas essas definições, podemos extrair que as instituições fazem parte do imaginário social e são dotadas de funções e expectativas, conforme as inscrições das organizações em um determinado campo: saúde, educação, jurídico, entre outros. Portanto, não poderíamos nos abster sobre a questão da dupla vinculação que os pacientes estão expostos, quando se faz referência a trabalhos psicológicos dentro do âmbito institucional.

Por um lado, tem-se a relação transferencial dos pacientes com 0 psicólogo / terapeuta do grupo. Relação desejada e até certo ponto estimulada, na 
medida em que é caracterizada como o motor de tratamento e cura. Por outro lado, tem-se a relação transferencial dos pacientes com a instituição em questão.

Freud (1912/1987c) nos esclarece que a transferência é constituída por fantasias em torno do objeto em questão. Essas fantasias têm o teor de reminiscências infantis das relações primitivas do sujeito que são atualizadas no novo contexto. Concluímos, portanto, que a qualidade da relação do sujeito com a instituição está em jogo durante todo o tratamento e podemos observar seus efeitos nas queixas e nos sintomas dos pacientes, uma vez que tendem a se repetir.

Em seu texto "O mal-estar na civilização", Freud (1930/1987p) aponta que o ser humano tende a idealizar quando defrontado com o desamparo. Assim, uma instituição que tem por objetivo promover a saúde, de certa forma está oferecendo-se como depositária de expectativas messiânicas.

Ainda segundo Freud (1927/1987o), as religiões cumprem essa função na cultura, ou seja, evitam o mal-estar causado pela vivência de desamparo. Lembremos que, originalmente, os hospitais estão ligados às funções religiosas e costumam ser nomeados com referências religiosas. Por conseguinte, o hospital e seus representantes (médicos, psicólogos e outros profissionais) ocupam tal lugar no imaginário social.

Em estando os grupos terapêuticos aqui referidos inseridos em um âmbito institucional, é de interesse deste trabalho o modo como a vida psíquica está inscrita na instituição, na medida em que o sujeito traz dentro de si os elementos da instituição.

Segundo Bleger (1984), as instituições tendem a adotar e repetir a mesma estrutura dos problemas que têm de enfrentar. Compreendemos então que a dissociação mente / corpo, tão comum entre os usuários de um hospital, também 
pode se encontrar presente nas equipes de saúde. Além disso, a concepção que o terapeuta tem da instituição, e dos valores por ela impostos ao campo terapêutico, deve provavelmente se manifestar nos dispositivos de cura através de processos inconscientes.

Tendo em vista o exposto, toda instituição cumpre uma função psíquica para cada um de nós. Essa função chamamos função objeto. Cabe à função social o papel de senso comum das instituições, como, por exemplo, o hospital cumpre uma função social de promover a saúde. Logo, podemos afirmar que existe uma realidade psíquica própria de cada instituição, além da realidade psíquica de cada sujeito dentro de uma instituição.

Todos os fenômenos próprios do campo grupal, que neste trabalho nos preocupamos em explicitar e analisar, não são propriedade privada dos grupos terapêuticos, como também não são estranhos à equipe na qual o profissional está inserido. Observamos que essas manifestações da estrutura grupal estão dentro de cada um de nós e têm origem em nosso grupo de pertencimento primário.

A Psicanálise não foge à regra. Em relação à transmissão e à formação de analistas, a própria psicanálise, em sua história e desenvolvimento, parece estar sujeita ao grupo desde sua fundação a partir de Freud e a Sociedade das Quartas-Feiras (1902). Nota-se que Freud convoca um grupo ao seu redor, e mais de um semelhante é necessário para que se dê origem à psicanálise.

A partir de então, seguem-se inúmeras Sociedades de Psicanálise com vistas à formação e à troca clínico-teórica. Trata-se, portanto, de uma dupla necessidade, uma vez que a prática do psicanalista é altamente individualizada, mas, paradoxalmente, tem a necessidade de se comunicar e dialogar em grupo. 
Em relação à instituição psicanalítica, o grupo cumpre a sua função de apoio perlaborativo e criador, mantendo e conservando a sua função humanizante, por meio da passagem da horda ao grupo pela travessia do complexo de Édipo (Kaës, 1997).

Hoje em dia, cada vez mais psicanalistas trabalham em instituições onde ensinam, dirigem, clinicam e nelas exercem funções hierárquicas.

O sujeito singular, que inicialmente descrevemos, foi-se tornando cada vez mais complexo: sujeito do inconsciente, sujeito do grupo e neste momento sujeito da instituição.

Ao encerrar este capítulo reiteramos o duplo desafio presente no trabalho psicanalítico com grupos em uma instituição: o trabalho teórico e o trabalho prático - ambos são estranhos ao ambiente natural do psicanalista. 
A apresentação de materiais clínicos tem por objetivo ilustrar algumas das proposições teóricas discutidas até o presente momento. Conseqüentemente, não podemos - e nem pretendemos - esgotar as inúmeras análises possíveis dos fenômenos presentes em cada fragmento de sessão descrito a seguir. Também não há nenhuma intenção de discorrer sobre o trabalho intrapsíquico e intersubjetivo de cada paciente em questão.

Optamos por recortes específicos e temos ciência de que muita informação não foi abarcada, haja vista a diversidade de fenômenos presentes nas sessões de grupos. Além disso, cada processo contém sua própria historicidade, por essa razão relatar um fragmento implica sempre focalizar a atenção em alguns aspectos, em detrimento de outros.

Os relatos das sessões são recortes que foram reconstruídos a partir da memória do analista e retificamos que a sua principal finalidade é a de possibilitar a articulação do material clínico com a teoria. Essa é a condição na qual todo o levantamento bibliográfico poderá ser articulado e, quiçá, elucidar algumas das inquietações. 
5.1 Fragmento 1

Sessão de um grupo psicoterápico aberto composto por oito mulheres na faixa etária entre 40 e 59 anos de idade.

As pacientes entram na sala agitadas e todas falando ao mesmo tempo sobre o fim do mundo (3).

A porta-voz do tema é uma pessoa particularmente desamparada em suas questões e conflitos pessoais. Aflita, dirige-se ao grupo e à terapeuta, a fim de saber se todas tinham ouvido falar sobre o tema que Ihe assustava. Por meio da interdiscursividade, colocaram-se as diferentes posições. Alguns depoimentos apontam para aquelas que ouviram, mas acham uma bobagem; outras ouviram e não se preocupam, porém ficam ansiosas aguardando a data; também há aquelas que não sabiam de nada e, finalmente, as que entenderam que o fenômeno marca uma mudança, mas não necessariamente o "fim do mundo".

Num fenômeno típico de ressonância grupal, as associações seguem para situações que aludem a perdas externas e internas vivenciadas em diferentes graus de intensidade. Essas situações vão desde uma simples alusão até a possibilidade extrema da incapacidade de agir e pensar - a posição confortável e amparada do ego ideal ficou, portanto, ameaçada.

(3) Essa sessão acontece dois dias antes do "fim do mundo", profetizado por Nostradamus em 1998. 
A seguir, a titulo de ilustração, algumas vinhetas das falas de pacientes:

_ Meu marido continua agressivo comigo e com a minha filha, qualquer coisinha e ele já quer partir para a briga e vem em cima mesmo (...) eu não tenho como me defender dele...

_ Eu não sei mais o que fazer com o meu trabalho, não posso voltar lá, eu não suporto aquelas crianças e nem posso controlar elas.

_ A gente fica sem saber o que fazer nessas situações, não consigo nem pensar (...) é nessa hora que vejo o quanto estou sozinha no mundo!

Ao final dos relatos surge novamente a expressão "fim do mundo", mas agora num sentido diferente:

_ Eu estava ali atrasada e não sabia o que fazer com o pneu furado, tive vontade de sentar na rua e chorar (...) fiquei em pânico um tempo, aí me lembrei do macaco e quando estava mexendo lá veio um cara e me perguntou se queria ajuda. Acabou dando tempo de ir à audiência. Depois que tudo passou até achei graça e pensei: pois é, não foi o fim do mundo.

A terapeuta aponta para o grupo a presença insistente da expressão, mas também o sentido diferente de "fim de mundo" e de "fim do mundo". A qual mundo será que estão se referindo? 
O novo sentido foi denunciado pela terapeuta para o grupo por meio de uma interpretação, abrindo espaço para resignificar uma situação ameaçadora e desamparada, não mais de um lugar narcísico onipotente e negador da castração.

A colocação provoca risos nas componentes do grupo e a última paciente que falou, quando se dá conta do sentido duplo de sua fala, cobre sua boca com as duas mãos.

A questão desperta uma reflexão sobre as situações relatadas até então e vivenciadas como "fim do mundo". Até que uma paciente diz:

_ Olha só querida, pelo menos apareceu um homem útil na sua vida. Para essas coisas de carro eles servem.

As falas seguintes se voltam para as relações afetivas das pacientes e o que esperam dos homens. Uma das integrantes se dirige à única paciente solteira e sem namorado do grupo:

_ Você não sabe ainda, mas é a única aqui de nós que está feliz. Eu se fosse você parava com isso de querer casar, não vê o que a gente passa?

A terapeuta diz para o grupo que elas, em alguns momentos, sentemse muito desamparas, sem poder reagir em relação ao que as pessoas falam e fazem; e, em outros momentos, sentem-se tão poderosas e tão melhores.

Após o encerramento da sessão a paciente que inicia a sessão diz: 
Outra paciente Ihe diz:

_ Acho que ninguém aqui sabe, mas o que a gente quer te dizer é para não ficar assim do jeito que você está, porque se o mundo for acabar mesmo ninguém aqui pode fazer nada, nem a M.

Kaës (1997) esclarece que o laço grupal é constituído pela negatividade, ou seja, algo deve ter sido excluído e recalcado, e esse recalque deverá ser reafirmado pelo grupo ao qual o sujeito pertence. Os laços identificatórios remetem ao que está comumente recalcado no grupo.

Assim, podemos observar a ressonância que o assunto "fim do mundo" tem nas componentes do grupo: remetê-las a situações vivenciadas que ficaram registradas como "fim de mundo", o que pode estar apontando para a necessidade de cada membro do grupo manter fora de circulação o desamparo inerente à condição humana. Conseqüentemente, esse tema retorna como emergente para o grupo através de seu porta-voz, com um sentido persecutório marcado pelo pavor da destruição.

O tema emergente do grupo é, portanto, a via régia do trabalho do terapeuta e deve ser sempre respeitado, na medida em que expressa no porta-voz do grupo o conteúdo a ser trabalhado, a ser reintegrado e resignificado através de sua circulação.

Assim, a paciente aflita evidencia as vivências paranóicas de destruição e de desamparo, idéias com as quais o grupo trabalha intrapsiquicamente e intersubjetivamente, buscando, internamente, referenciais que auxiliem a transposição de tal vivência. Podemos observar também o verdadeiro sentido da 
expressão trabalho psíquico da intersubjetividade. Todo trabalho implica um paradoxo, ou seja, uma determinada quantidade de energia em favor da mudança e em contrapartida outro tanto de energia contra tal mudança. Assim, o tema "fim do mundo" é novamente retomado no final da sessão, tal como aparece em seu início.

Como descrevemos anteriormente, os trabalhos terapêuticos de grupos se desenrolam por meio de interjogo fantasmático entre o sujeito singular e o sujeito do grupo. Em virtude do exposto, observamos que as pacientes pertencentes a este grupo se encontram em diferentes posições em relação ao contato com sua própria subjetividade.

O grupo é o dispositivo no qual os conteúdos inconscientes podem transitar e se disponibilizar para o trabalho psíquico de mais de um outro. 


\subsection{Fragmento 2}

Sessão de um grupo psicoterápico fechado, composto por sete mulheres na faixa etária entre 39 e 60 anos de idade, muitas delas vivendo, coincidentemente, processos de luto. Na sessão relatada houve duas faltas.

A terapeuta relembra ao grupo que suas férias terão início na semana seguinte. As pacientes retomam o que falavam quando entraram na sala. O tema se refere às dores físicas e aos problemas de saúde. Após várias colocações de todas elas, uma das pacientes conclui:

_ É... estamos com problemas de junta como dizem por aí, sabe? Assim ó: junta tudo e joga fora.

Essa fala provoca intensos risos nas componentes do grupo.

A terapeuta aponta que o corpo de todas elas parece carregar muitas coisas e hoje estão falando através dele.

Laura (4) se dirige à terapeuta e ao grupo agradecendo pelo que disseram na sessão anterior sobre o dia das mães. Na época, Laura havia perdido um filho recentemente e o dia das mães foi seguido ao dia de aniversário do filho.

(4) Os referidos nomes são fictícios visando manter o sigilo e os preceitos éticos. 
Também diz que se deu conta que estava chorando bastante por razão da aproximação dessas datas, e que havia conversado sobre isso com uma filha.

As pacientes do grupo começaram a falar sobre as pessoas com as quais se pode contar e essas pessoas podem ser contadas nos dedos de uma mão. Elas concluem que podem contar apenas com um pequeno grupo.

A terapeuta aponta que no pequeno grupo de 5 pessoas ou dos dedos de uma mão podem falar sobre suas questões e que as suas férias será um impedimento para isso.

Após o encerramento da sessão, despedem-se e Laura se dirige ao grupo desejando um feliz dia das mães atrasado. Na sessão anterior, essa paciente dizia que somente quem é mãe poderia entendê-la, portanto não cumprimentaria ninguém pela data.

Segundo Puget \& Berenstein (1993), vínculo é uma estrutura de três termos constituída por dois pólos: os dois egos (descritos a partir de um observador virtual), ou um ego e outro (vistos a partir de si mesmo), e um conector (ou intermediário, na linguagem de Kaës), que dará conta da maneira particular de ligar ambos.

Notamos aqui que o grupo é tomado como esse objeto intermediário que sustenta as experiências intrapsíquicas comuns e compartilhadas entre os membros do grupo. Observamos, também, que esse espaço pode ser definido como semelhante, mas não necessariamente idêntico, ou seja, nem todos os processos de luto levam ao mesmo resultado. 
Podemos observar e discutir a importância dada ao corpo como depositário de todas as angústias. Esse é um fator que pode ser atribuído ao fato do grupo terapêutico estar inserido em uma instituição de saúde, ou seja, quase sempre as pacientes procuram os serviços médicos antes de chegarem ao serviço de psicologia. Tal fato denota a dificuldade de simbolização dessas pacientes, que recorrem ao corpo para expressar todos os tipos de mal-estares. 


\subsection{Fragmento 3}

Sessão de um grupo psicoterápico fechado, composto por seis mulheres na faixa etária entre 35 e 54 anos de idade.

O fragmento de sessão relatado a seguir faz parte do início do processo psicoterápico desse grupo.

Uma das pacientes vivenciou, há dois anos, uma intervenção cirúrgica que a angustia muito. Assim, desde o início dos atendimentos é uma paciente prolixa que ocupa todo o tempo e espaço das sessões, minimizando os relatos das outras componentes do grupo e solicitando muita atenção para si mesma. Tal situação era nitidamente desconfortável, porém nenhuma delas se sentia à vontade para verbalizar e expressavam o incomodo por vias não verbais - gestos, sons e olhares. Todas pareciam esperar que a terapeuta pudesse colocar em palavras aquilo que sentiam, sem que tivessem de comprometer a suposta boa relação que mantinham no grupo.

O grupo já se encontrava dentro da sala de atendimento quando uma das componentes adentrou ao ambiente com pressa e sem fôlego para avisar que teria uma consulta médica e, portanto, não poderia vir à sessão. Retirou-se do mesmo modo que entrou.

Sem fazer comentários sobre a situação, uma paciente inicia sua fala:

_ Esta semana fui assaltada quando voltava do supermercado com a minha mãe. Eu percebi um homem estranho, ele se aproximou e levou meu celular e a minha carteira. Mas, o que me espantou foi a minha 
reação: eu tentei correr atrás dele. Nem me reconheci, afinal eu sou uma pessoa que evito ao máximo entrar em uma confusão.

As associações do grupo seguem no sentido da violência, do quanto os professores têm perdido lugar para os traficantes nas escolas e do como sentem saudades do tempo em que eram exemplos de mestre.

Ao final dos comentários sobre as escolas, uma paciente retoma a sessão anterior, na qual a participante que toma todo espaço para si havia relatado uma questão familiar que estava vivenciando e exigido do grupo uma solução, já que ela tinha exposto sua vida. Diz ter se sentido mal com essa colocação, uma vez que não lhe ocorreu nada que valesse a pena para ajudá-la.

A terapeuta aponta que o grupo fala de uma série de situações de invasão. Algumas ocorrem dentro do próprio espaço terapêutico, no entanto demonstram entender que não podem explicitar tais situações. Caso contrário podem perder seu lugar no grupo, chegando inclusive a deixar de lado o fato de que alguém esteve ali para dizer que não estava ali.

Podemos observar nesse fragmento um fenômeno típico que ocorre nos grupos terapêuticos recém-formados. Esse fenômeno recebe diferentes denominações, dependendo do autor a quem nos referimos: D. Anzieu chamaria de Ilusão Grupal e R. Kaës de Grupo Ideológico.

Independente da nomenclatura, o estado que prevalece no grupo é o de bem-estar e de exclusão das diferenças, criando então um clima interno ao grupo de realização narcísica. Todas ali se compreendem e se complementam, todas as 
questões que incomodam estão projetadas e depositadas fora do grupo, tal como fizeram com a invasão de espaço.

O momento da ilusão grupal possui duas faces: é fundamental no início do trabalho grupal, pois auxilia na constituição da identidade grupal, na manutenção e prevalência dos vínculos afetivos amorosos. Porém, tal como o estágio narcísico da constituição do sujeito psíquico, deverá ser superado para que cada um dos sujeitos possa deixar surgir, compartilhar, conviver e superar os antagonismos e os conflitos.

Freud (1913/1987e , 1921/1987I) descreve que o primeiro sentimento despertado pelo irmão semelhante é o de ódio, na medida em que a presença desse outro impõe a perda dos privilégios narcísicos. Observamos, muitas vezes, nos fenômenos de massa um ódio indiscriminado que nos remete a essa vivência primitiva. O grupo, tal como descrito neste trabalho, exige dos sujeitos uma organização diferente, pois supera a organização da horda. 
A Organização Mundial da Saúde (OMS) (2005) recomenda as técnicas grupais como forma de democratizar o acesso aos programas e projetos preventivos de saúde, uma vez que o grupo contempla a idéia não só das questões intrapsíquicas, mas também das relações sociais. Cada vez mais está-se privilegiando o pressuposto que o ser humano é multideterminado, inclusive no aspecto dos processos psíquicos. Além disso, os grupos terapêuticos podem se configurar como um veículo de promoção de saúde.

Aplicaremos aqui a noção de Bleger (1998) sobre a expressão promover saúde, ou seja, saúde não se limita apenas à ausência de doença. O conceito é mais amplo de maneira a aproveitar eficientemente todos os recursos na procura de melhores condições de vida em todos os campos: material, cultural, social e psicológico. Dessa forma, fica explicitada a finalidade do trabalho com grupos terapêuticos em uma instituição de saúde: possibilidades do devir das capacidades humanas.

A sociedade atual é marcada pela exaltação narcísica que põe em risco o importante sentimento de pertença, comprometendo a singularidade no sentido da individuação do sujeito, na medida em que há um esvaziamento da relação de responsabilidade com o semelhante. Assim, os grupos podem indiretamente lembrar que o sujeito desenvolve seus próprios valores, considerando a existência dos outros e não independente dela. 
Se considerarmos que as patologias do traumatismo são as grandes fontes do sofrimento contemporâneo e, tal como foi exposto até então, encararmos esses traumatismos como falhas de simbolização do sistema pré-consciente e, conseqüentemente, da constituição intrapsíquica efetuada na intersubjetividade, podemos ter uma compreensão da função dos grupos.

Cada vez mais o encontro libidinal com os semelhantes está sendo substituído por métodos mais modernos de comunicação, levando o sujeito à busca frenética e desenfreada de informações novas e de possuir os últimos lançamentos de objetos que o mantenha conectado ao mundo externo. $O$ mundo interno tem perdido sua relevância e sua significação. Conseqüentemente, a linguagem e a palavra já não são os únicos veículos de acesso ao inconsciente, levando-se em consideração que, principalmente, nas novas formas de subjetivação, o inconsciente não pode ser apreendido como sinônimo do recalcado. Podemos pensar que a modernidade tem imposto ao psicanalista decifrar uma subjetividade cada vez mais ausente de sujeito.

Assim, notamos um crescente índice de violência gerada, principalmente, por movimentos de intolerância com aquilo que se apresenta diferente de nós. Observamos, também, encontros nos quais o outro é tratado apenas como um corpo, como um objeto de gozo, e não um sujeito desejante, portanto semelhante. O imediatismo propõe como resolução a descarga pulsional em direção ao acting out.

Nas sociedades modernas, observam-se traços do mesmo processo apontado por Freud em "Psicologia das massas e a análise do ego". Em alguns momentos uma nostalgia do líder e, em outros, reações de hostilidade e intolerância às diferenças (Cavalcanti, Cardoso \& Rocha, 2000). 
O desamparo, sinal ostensivo da fragilidade humana (...) é um marco da experiência contemporânea. Num mundo sem garantias e certezas asseguradas, a existência torna-se para o sujeito uma aventura de riscos insuportáveis e as soluções construídas para enfrentar o mal-estar, sempre provisórias, não eliminam a ameaça do desamparo (Cavalcanti et al., 2000, p. 124).

Parece-nos que a saída para tal estado de desamparo vem ao encontro das idéias de Birman (1999) para a sublimação: um trabalho incessante sobre o mal-estar, considerando-se que esse sentimento implica a constatação da castração simbólica de todos nós.

A castração também põe em cena o desamparo, mas desempenha importante papel na constituição do sujeito psíquico, quais sejam: a possibilidade de destituição de posições narcísicas; a abdicação dos ideais de totalidade, de plenitude e de onipotência; a constatação dos frágeis limites do possível no confronto incessante com os desejos que aspiram, com soberania, à impossível plenitude (Cavalcanti et al., 2000).

O individualismo moderno promove o recalque do caráter coletivo do que determina nossos atos - isto é justamente o que precisa ser recuperado para restaurar a confiança dos sujeitos no laço social, em relação ao qual somos todos, ao mesmo tempo, agentes e objetos (Kehl, 2000, p. 34).

Não podemos nos furtar de abordar um tema tão delicado quando se fala de psicanálise e grupos. Às vezes entende-se que os grupos são um modo de fazer a psicanálise atingir uma determinada parcela da população que não teria acesso ao tratamento por intermédio de consultório particular.

É sabido que não podemos adotar o local e as condições como o contexto em excelência para se falar de psicanálise, tampouco reduzi-la ao local onde é praticada. 
Lembramos, portanto, que a psicanálise não pretende ser a solução de todos os problemas e tampouco das injustiças sociais. Esse tema faz parte de uma outra reflexão e não diz respeito à técnica grupal.

O trabalho com grupos pode contribuir para o tratamento psíquico dos pacientes ligados a uma instituição, na medida em que se caracteriza como um método terapêutico que tem por objetivo promover mudanças intrapsíquicas por meio da intersubjetividade. Observamos que as relações do sujeito psíquico com o outro semelhante podem propiciar alterações psíquicas que contribuem para o tratamento do sofrimento humano.

As questões levantadas neste capítulo estão circunscritas à prática clínica atual e devem ser levadas em consideração por todo analista. 
Finalizar um trabalho é sempre uma tarefa muito enredada, há sempre um quê a se discutir e refletir. Somam-se a essa dificuldade as tomadas de decisões que priorizaram determinadas questões em prol de outras. No entanto, faz-se premente interromper a discussão para dar oportunidade ao nascimento de novas idéias. Um trabalho, no sentido psicanalítico do termo, é sempre e por premissa inacabado e conflitivo.

Posto essas ponderações, resta-nos retomar algumas questões abordadas neste trabalho com o intuito de, momentaneamente, finalizá-lo.

Como já exposto na apresentação e na introdução, o tema de grupos, no contexto de uma concepção psicanalítica, é árduo, denso e complexo, na medida em que apresenta variadas vertentes e inúmeras influências de diversas áreas de conhecimento. Portanto, a retomada da leitura freudiana teve por objetivo esclarecer as concepções posteriores sobre o tema.

Ao se retomar a constituição do sujeito psíquico, observamos que, em grande parte, esse fenômeno ocorre por meio da relação intersubjetiva. Logo, podemos inferir que as manifestações sintomáticas estão, inevitavelmente, imbricadas no sofrimento advindo das relações com o semelhante.

Tendo em vista que os fatores inerentes à grupabilidade humana expressam sua presença nas manifestações sintomáticas físicas e/ou psíquicas, a abordagem terapêutica grupal pode facilitar o acesso a essas manifestações. Os efeitos da terapêutica grupal são efeitos de estruturação simbólica de relação de 
semelhantes, de subjetivação e de interdependência subjetivantes (Kaës, 1994, p. 35).

Abordamos questões sobre o dispositivo grupal que implicam discussões sobre a técnica psicanalítica. Geralmente, quando é feita uma referência à psicoterapia de grupo, sempre a fazemos mediante a comparação com a psicoterapia individual, mais conhecida e melhor dominada pelos psicoterapeutas. Tal recurso se mostra inadequado já que são instrumentos diferentes, porém aquilo que circula entre os profissionais da área chega intacto aos pacientes: um préconceito a respeito da técnica.

Lembramos que este trabalho se desenvolveu no ambulatório de Psicologia do Hospital do Servidor Público Estadual justificando, portanto, toda a preocupação em circunscrever o campo institucional e seu significado psíquico.

Ao longo desses anos observamos que, quando o grupo é tratado como um dispositivo de tratamento e não como um paliativo, enquanto aguardam o atendimento individual - o verdadeiro tratamento, os usuários de um serviço de Psicologia em uma Instituição de Saúde valorizam seus tratamentos, facilitando o estabelecimento do tão necessário vínculo transferencial. Desse modo, tendem a não retornar à Seção de Psicologia do Hospital, pois já se consideram "atendidos", ou seja, essa postura colabora efetivamente com a circulação da demanda, sob o ponto de vista não quantitativo.

A origem deste trabalho foi uma inquietação e um certo desconforto em relação à prática clínica institucional e a teoria na qual se articulava essa clínica, a psicanálise. 
A formulação da questão pode ser substanciada da seguinte forma: a psicanálise pode trazer alguma contribuição às Instituições e ao atendimento de grupos?

Na questão objeto, a Instituição é Hospitalar, especificamente um ambulatório de psicologia que recebe grande número de pacientes, ou seja, um vasto campo de experiência clínica. Campo em que se operaram todas as teorias aqui propostas, o que possibilitou o tema do trabalho. Âmbito que define a psicanálise como processo de investigação, em que a contribuição é sempre mútua: analista / paciente, teoria / clínica, psicanálise / instituição. 


\section{REFERÊNCIAS}

Anzieu, D. (1993). O grupo e o inconsciente - o imaginário grupal. São Paulo: Casa do Psicólogo.

Baranger, W., Del Campo, E., Goldstein, R., Merea, E.C., Mom, J. M., \& Resnicoff, B. et al. (1994). Contribuições ao conceito de objeto em psicanálise. São Paulo: Casa do Psicólogo.

Baremblitt, G., Guattari, F., \& Leitão, M. B. S. (1986). Grupos teoria e técnica. Rio de Janeiro: Graal.

Berenstein, I. (2003). Reflexões sobre uma psicanálise do vínculo. In: Green, A. (Org). Psicanálise contemporânea: revista francesa de psicanálise: número especial, 2001. Rio de Janeiro: Imago.

Bernard, M. (2003). El psicoanálisis de las configuraciones vinculares. FLAPAG Federação Latino-Americana de Psicoterapia Analítica de Grupo, Buenos Aires, Argentina. Recuperado em 13 jan. 2003: http:// www.psinet.com.ar

Bion, R. W. (1948/1975). Experiências com grupos. Rio de Janeiro: Imago.

Birman, J. (1999). O mal-estar na atualidade: a psicanálise e as novas formas de subjetivação. Rio de Janeiro: Civilização Brasileira. 
Bleger, J. (1984). Psico-higiene e psicologia institucional. Porto Alegre, RS: Artes Médicas.

Bleger, J. (1998) Temas de psicologia - entrevista e grupos. São Paulo: Martins Fontes.

Cavalcanti, E. A ., Cardoso, C. , \& Rocha, S. P. (2000). Reflexões sobre a instituição psicanalítica na contemporaneidade. In: Kehl, M. R. (Org.). Função Fraterna. Rio de Janeiro: Relume Dumará.

Correa, O. B.R. (Org.). (2002). Vínculos e instituições - uma escuta psicanalítica. São Paulo: Escuta.

Costa, J. F. (1989). Psicanálise e contexto cultural: imaginário psicanalítico, grupos e psicoterapia. Rio de Janeiro: Campus.

Diálogo Berenstein - Kaës. Recuperado em 21 set. 2005: http://www.apdeba.org

Houaiss, A . (2005). Alteridade. In: Dicionário Houaiss da Língua Portuguesa. Recuperado em 17 jul. 2005: http://www.houaiss.uol.com.br

Fernandes, M. I. A. (2003a). Mestiçagem e ideologia - algumas reflexões sobre a negatividade na construção dos laços sociais. Tese de livre docência, Instituto de Psicologia, Universidade de São Paulo, São Paulo. 
Fernandes, M. I. A. (2003b). O trabalho psíquico da intersubjetividade. Psicologia USP, 14 (3).

Fernandes, S. B., \& Fernandes, J. W. (2003). Aspectos intra e transubjetivos da grupabilidade. FLAPAG - Federação Latino-americana de Psicoterapia Analítica de Grupo, Buenos Aires, Argentina. Recuperado em 13 jan. 2003: http:// www.psinet.com.ar .

Fernandes, J. W., Svartman, B., \& Fernandes, S. B. et al. (2003). Grupos e configurações vinculares. Porto Alegre, RS: Artmed.

Figueiredo, A. C. (1997). Vastas confusões e atendimentos imperfeitos - a clínica psicanalítica no ambulatório público. Rio de Janeiro: Relume Dumará.

Figueiredo, A. C. (Org.). (2001). Psicanálise - pesquisa e clínica. Rio de Janeiro: IPUB/CUCA.

Freud, S. (1895/1987a). Projeto para uma psicologia científica. (Obras Psicológicas Completas de Sigmund Freud, vol. I). Rio de Janeiro: Imago.

Freud, S. (1905/1987b). Os três ensaios sobre a teoria da sexualidade. (Obras Psicológicas Completas de Sigmund Freud, vol. VII). Rio de Janeiro: Imago.

Freud, S. (1912/1987c). A dinâmica da transferência. (Obras Psicológicas Completas de Sigmund Freud, vol. XII). Rio de Janeiro: Imago. 
Freud, S. (1912/1987d). Recomendações aos médicos que exercem a psicanálise. (Obras Psicológicas Completas de Sigmund Freud, vol. XII). Rio de Janeiro: Imago.

Freud, S. (1913/1987e). Totem e tabu. (Obras Psicológicas Completas de Sigmund Freud, vol. XIII). Rio de Janeiro: Imago.

Freud, S. (1914/1987f). Sobre o narcisismo: uma introdução. (Obras Psicológicas Completas de Sigmund Freud, vol. XIV). Rio de Janeiro: Imago.

Freud, S. (1915/1987g). Os instintos e suas vicissitudes. (Obras Psicológicas Completas de Sigmund Freud, vol. XIV). Rio de Janeiro: Imago.

Freud, S. (1917/1987h). Luto e Melancolia. (Obras Psicológicas Completas de Sigmund Freud, vol. XIV). Rio de Janeiro: Imago.

Freud, S. (1919/1987i). O estranho. (Obras Psicológicas Completas de Sigmund Freud, vol. XVII). Rio de Janeiro: Imago.

Freud, S. (1919/1987j). Sobre o ensino da psicanálise nas universidades. (Obras Psicológicas Completas de Sigmund Freud, vol. XVII). Rio de Janeiro: Imago.

Freud, S. (1920/1987k). Além do princípio de prazer. (Obras Psicológicas Completas de Sigmund Freud, vol. XVIII). Rio de Janeiro: Imago. 
Freud, S. (1921/1987). Psicologia de grupo e a análise do ego. (Obras Psicológicas Completas de Sigmund Freud, vol. XVIII). Rio de Janeiro: Imago.

Freud, S. (1923/1987m). O ego e o id. (Obras Psicológicas Completas de Sigmund Freud, vol. XIX). Rio de Janeiro: Imago.

Freud, S. (1925/1987n). A negativa. (Obras Psicológicas Completas de Sigmund Freud, vol. XIX). Rio de Janeiro: Imago.

Freud, S. (1927/1987o). O futuro de uma ilusão. (Obras Psicológicas Completas de Sigmund Freud, vol. XXI). Rio de Janeiro: Imago.

Freud, S. (1930/1987p). O mal-estar na civilização. (Obras Psicológicas Completas de Sigmund Freud, vol. XXI). Rio de Janeiro: Imago.

Freud, S. (1939/1987q). Moisés e o monoteísmo três ensaios. (Obras Psicológicas Completas de Sigmund Freud, vol. XXIII). Rio de Janeiro: Imago.

Garcia-Roza, A . L. (1995). Introdução à metapsicologia freudiana 3. Rio de Janeiro: Jorge Zahar.

Gay, P. (1989). Freud, uma vida para o nosso tempo. São Paulo: Companhia das Letras. 
Gibeault, A. (2003). Do processo analítico em psicanálise e psicoterapia: do interpessoal ao intrapsíquico. In: Green, A. (Org). Psicanálise contemporânea: revista francesa de psicanálise: número especial, 2001. Rio de Janeiro: Imago.

Grinberg, L., Langer, M., \& Rodrigue, E. (1976). Psicoterapia de grupo: enfoque psicanalítico. Rio de Janeiro: Forense Universitária.

Kaës, R., Missenard, A ., Kaspi, R., Anzieu, D., Guillaumin, J. \& Bleger, J. (1979). Crisis, ruptura y superación. Buenos Aires: Ediciones Cinco.

Kaës, R., Bleger, J., Enriquez, E., Fomari, F., Fustier, P., \& Roussillon, R. et al. (1991). A instituição e as instituições. São Paulo: Casa do Psicólogo.

Kaës, R. (1994). La invención psicoanalítica del grupo. Buenos Aires: Asociación Argentina de Psicología y Psicoterapia de Grupo.

Kaës, R. (1997). O grupo e o sujeito do grupo. São Paulo: Casa do Psicólogo.

Kaës, R. (2003a). O intermediário na abordagem psicanalítica da cultura. Psicologia USP, 14 (3).

Kaës, R. (2003b). A negatividade: problemática geral. Psicologia USP, 14 (1).

Kaës, R. (2004). Complejidad de los espacios institucionales y trayectos de los objetos psíquicos. Psicoanálisis AP de BA, XXVI, (3). 
Kaës, R. (2005). Os espaços psíquicos comuns e partilhados: transmissão e negatividade. São Paulo: Casa do Psicólogo.

Kehl, M. R. (2000). Função fraterna. Rio de Janeiro: Relume Dumará.

Laplanche, J. \& Pontalis, J-B. (1986). Objeto. In: Vocabulário da psicanálise. São Paulo: Martins Fontes.

Mezan, R. (1993). O que significa "pesquisa" em psicanálise?. In: Silvia, M.E.L. (Coord.). Investigação e psicanálise. Campinas: Papirus.

Moscona, L. S. (1999). La función psicoanalítica: atravesamientos. FLAPAG Federação Latino-Americana de Psicoterapia Analítica de Grupo, Buenos Aires, Argentina. Recuperado em 27 ago. 1999 em: http://www.psinet.com.ar

Organizacion Mundial De La Salud (2005). Recuperado em 18 jul. 2005: http://www.who.int

Puget, J. \& Berenstein, I. (1993). Psicanálise do casal. Porto Alegre: Artes Médicas.

Quinet, A. (2000). As $4+1$ condições da análise. Rio de Janeiro: Jorge Zahar.

Rouchy, C. J. \& Desroche, S. M. (2005). Instituição e mudança - processo psíquico e organização. São Paulo: Casa do Psicólogo. 
Roudinesco, E. \& Plon, M. (1998). Dicionário de psicanálise. Rio de Janeiro: Jorge Zahar.

Safra, G. (1993). O uso de material clínico na pesquisa psicanalítica. In: Silvia, M.E.L. (Coord.). Investigação e psicanálise. Campinas, SP: Papirus.

Sartre, J-P. (2005). Entre quatro paredes. Rio de Janeiro: Record.

Sigal, M. A. (1989). Psicanálise, grupos, instituição pública. Percurso - Revista de Psicanálise, ano I, (2).

Sonenreich, C. \& Estevão, G. (1996). Psiquiatria no Hospital Geral: atividades no Hospital do Servidor Público Estadual "Francisco Morato de Oliveira". Temas Teoria e Prática do Psiquiatra. Grupo de Estudos Psiquiátricos do Hospital do Servidor Público Estadual - FMO, 26, (52).

Winnicott, D. W. (1975). O brincar e a realidade. Rio de Janeiro: Imago.

Zimmermann, D. (1971). Estudos sobre psicoterapia analítica de grupo. São Paulo: Mestre Jou. 